\title{
"WHITHER, THEN, ARE YOU SPEEDING, O RUSSIA OF MINE? »': WHAT DO SCIENTISTS THINK ABOUT THE NEW SYSTEM OF THEIR LABOR EVALUATION IN RUSSIA
}

\author{
Karelin D.V. ${ }^{1,2}$, Glagolev M.V. ${ }^{3,4,5}$, Sabrekov A.F.4 \\ ${ }^{1}$ Institute of Geography, Russian Academy of Sciences, Moscow, Russia \\ ${ }^{2}$ Center for Forest Ecology and Productivity, Russian Academy of Sciences, Moscow, Russia \\ ${ }^{3}$ Lomonosov Moscow State University, Moscow, Russia \\ ${ }^{4}$ Yugra State University, Khanty-Mansyisk, Russia \\ ${ }^{5}$ Institute of Forest Science, Russian Academy of Sciences, Uspenskoe (Moscow region), Russia
}

Corresponding authors: m_glagolev@mail.ru

Citation: Karelin D.V., Glagolev M.V., Sabrekov A.F. 2020. «Whither, then, are you speeding, 0 Russia of mine?»: What do scientists think about the new system of their labor evaluation in Russia // Environmental dynamics and global climate change. V. 11. N. 2. P. 104-124.

DOI: $10.17816 /$ edgcc52983

This discussion paper is timed to the implementation of a new ranking system for assessing the scientific activities of RAS institutes in Russian Federation. Just as the scientific community was divided into supporters and opponents of this system, in the same way, enemies and followers of this system appeared in the editorial board of our journal. The positions of the first were voiced by D.V. Karelin, second - M.V. Glagolev. A.F. Sabrekov made an attempt to compare the declared arguments and formulate the outcome of the discussion.

The article discusses the issues of the funding sufficiency for Russian science, the contribution of Russian scientists to the total number of publications around the world, the salaries of scientists and funding for research through grants, the work of various systems for evaluating the work of scientists adopted both in universities and academic institutions, the impact of this systems for the development of Russian scientific journals, the functioning of the modern scientific process, etc. Various administrative solutions of the accumulated problems are proposed by both sides in the discussion. Particular examples illustrate how the effectiveness of scientists actually varies and how the activity of female scientists differs from male scientists in Russia.

It is concluded that the entire architecture of the system, including the managing of scientific journals, and the distribution policy of salaries and grants, and the work effectiveness assessment both for institutions and individual scientists, should be self-consistent. Multidirectional changes in the elements of the system separate from each other lead to disappointment of scientists in the government policy and Russian science at all, and, as a result, the emigration of talented young scientists.

Key words: scientometrics, Russian science policy, journal ranking, Russian Science Foundation

Предлагаемая читателям дискуссионная статья написана по мотивам принятия в РФ новой балльной системы оценки научной деятельности институтов РАН. Подобно тому, как научное сообщество разделилось на сторонников и противников данной системы, точно так же и в редакции нашего журнала обнаружились свои враги и приверженцы этой системы. Позиции первых озвучил д.б.н. Д.В. Карелин, вторых - к.б.н. М.В. Глаголев. А.Ф. Сабреков сделал попытку сопоставить высказанные аргументы и сформулировать итог дискуссии.

В статье обсуждаются вопросы специфики современного научного процесса, достаточности финансирования российской науки, вклада российских учёных в общее количество публикаций по всему миру, оплаты труда учёных и финансирования исследований за счёт грантов, работы различных систем оценки труда учёных, принятых как в ВУЗах, так и в академических институтах, влияния этой системы на развитие отечественных научных журналов, и т.д. С обеих сторон дискуссии предлагаются различные административные решения накопившихся проблем. На конкретных примерах показано, насколько на самом деле отличается эффективность учёных и как различается активность учёных-женщин и учёных-мужчин.

Делается вывод о том, что вся архитектура системы, включая и организацию научных журналов, и политику распределения ставок и грантов, и оценку эффективности работы институтов и отдельных учёных, должна быть самосогласована. Разнонаправленные изменения элементов системы по отдельности ведут к разочарованию учёных в политике государства и отечественной науке, и, как следствие, к отъезду талантливой молодёжи за границу.

Ключевые слова: наукометрия, научная политика в России, рейтинг журналов, Российский Научный Фонд

«О Русь, куда несешься ты?» - знаменитая фраза Н.В. Гоголя, завершающая его бессмертные «Мертвые души». Мы используем ее в названии статьи в английском переводе John Cournos (известного переводчика русской литературы Ивана Григорьевича Коршуна, родившегося в Житомире, на Украине, и эмигрировавшего в США). 


\section{Используемые сокращения:}

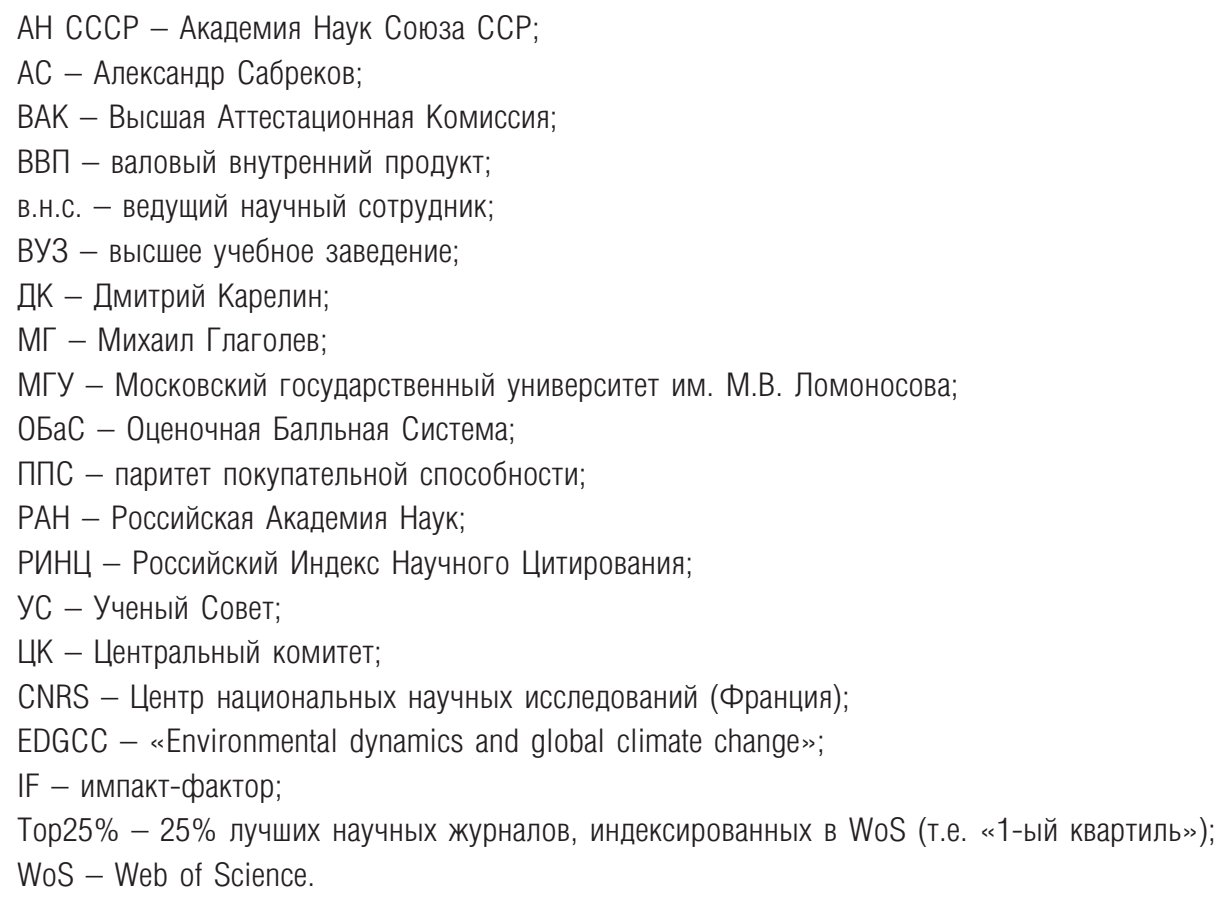

Дела все еще не так плохи, чтобы рассчитывать на улучшение.

Л.В. и А.Л. Шебаршины

Академик Ариимович выразил в свое время глубокую мысль о том, что в России есть две структуры, которые совершенно не подвержены реформам и не могут быть реформированы никогда, - это Церковь и Академия наук.

С.А. Кислицын

\section{BBEQEEHИE}

Измерение научной продукции (производительности) является сейчас настолько повсеместно принятым, что определяет большинство значимых вещей: иметь постоянную должность или быть безработным, получить грант или нет, быть успешным или провальным [Lawrence, 2008]. Поэтому неудивительно, что связанные с таким измерением вопросы широко обсуждаются в научных, научно-популярных и нормативных публикациях [Васьковский, 1994; Lawrence, 2008; Глаголев и Суворов, 2009; Кузьмин, 2020], в том числе и в разд. «Дискуссии» на страницах EDGCC: [Глаголев и Лапшина, 2012; Глаголев и др., 2012; 2018; Glagolev and Sabrekov, 2019]. Поводом для написания настоящей статьи явилось принятие в РФ новой балльной системы оценки научной деятельности институтов РАН. Подобно тому, как научное сообщество разделилось на сторонников и противников данной системы, точно также и в редакции EDGCC обнаружились свои враги и приверженцы этой системы. Ярким представителем первых оказался д.б.н. Д.В. Карелин (ДК), а вторых - к.б.н. М.В. Глаголев (МГ).

Ранее формат «Дискуссий» в EDGCC предполагал написание одним автором (или группой авторов) статьи, открывающей дискуссию, затем написание ответа ему - другой статьи или статей - другими авторами. Однако для читателя не всегда удобно выискивать в разных номерах журнала (в разных статьях) аргументы спорящих сторон. Поэтому мы решили написать общую статью, в которой слово будет поочередно предоставлено обеим сторонам ${ }^{2}$. При этом постара-

2 Оценивая представленную ниже дискуссию, нужно учитывать специфику взгляда дискутирующих. По образному выражению одного из рецензентов, «зачастую создается ощущение, что оба участника дискуссии существуют в разных «мирах» и говорят про разные вещи». Отчасти это объясняется тем, что ДК работает в структурах РАН, в то время как для МВ основным местом работы является МГУ (впрочем, там он трудится на научной должности, а не преподавательской). Это накладывает отпечаток на их взгляды, поскольку методики оценки научной деятельности в РАН и ВУЗах сильно отличаются и изменяются, подчас, в разных направлениях. 
лись соблюсти правило: изначально 3 каждому из спорящих дается равный объем текста (конкретные примеры, приводимые МГ и насыщенные малоинтересной для широкого круга читателей наукометрической статистикой, было решено вынести в Приложения). Поскольку в написании статьи изъявил желание принять участие еще и Александр Сабреков (АС), то, по предложению ДК, в заключение дискуссии АС - в качестве «рефери» - даст оценку аргументам ДК и МГ. Для удобства читателей, высказывания ДК набраны курсивом, а мысли АС собраны в разделе ЗАКЛЮЧЕНИЕ.

И, завершая это краткое Введение, отметим, что, поскольку все авторы работают в области экологии, то приводимые ниже примеры почерпнуты именно оттуда, а аргументы сторон в полной мере могут быть отнесены, казалось бы, лишь к положению дел в этой науке. Тем не менее, насколько нам известно, положение вообе в отечественных естественных науках примерно такое же, как и в экологии, так что наше обсуждение в некотором приближении может быть распространено и на них. Что же касается наук гуманитарных, то ситуация там известна нам гораздо хуже и на ее анализ мы не претендуем.

\section{anckyccng}

ДК: недавно я проанализировал свободно pacnространяемый Clarivate Analytics ${ }^{4}$ ежсегодный отчет о состоянии науки в странах G20 - крупнейших экономик мира, куда мы тоже входим. Вот список этих стран: США, Канада, Мексика, Австралия, Аргентина, Бразилия, Саудовская Аравия, ЮАР, Китай, Индия, Индонезия, Южнная Корея, Япония, Россия, Туриия, Великобритания, а также Германия, Франция, Италия и, отдельно, весь остальной Евросоюз.

Тут я нашел для себя довольно много любопытного. В частности, обращает на себя внимание относительно низкое число ученых в РФ, как в абсолютном выражении, так и долевом.

3 В дальнейшем это правило разрешено было нарушить, поскольку рецензенты сделали разное количество замечаний к текстам соавторов, что, соответственно, потребовало от последних дополнений или сокращений существенно разного объема.

4 The Annual G20 Scorecard; https://clarivate.com/ webofsciencegroup/campaigns/the-annual-g20-scorecardresearch-performance-2019/, русская версия доступна, например, по адресу: https://www.herzen.spb.ru/uploads/ amarkovicheva/files/\%D0\%B4\%D0\%BE\%D0\%BA\%D0\%B B\%D0\% B0\%D0\%B4.pdf. Clarivate Analytics - компания владеющая платформой Web of Science (WoS). Соответственно ниже обсуждаются только данные, полученные на основе базы WoS.
Первый показатель важен как двигатель науки, поскольку, при прочих равных, чем больше ученых в стране, тем сильнее наука (Китай здесь абсолютный лидер - более 2 млн. ученых), второй показатель работает как двигатель просвещения населения, т.к. чем больше вероятность встретиться с учеными (это зависит от их плотности), тем шире народ просвещается. Вот тут Китай (ученые составляют $0.15 \%$ населения), как и мы (0.25\%), - далеки от лидерства, а на первых местах стоят ведущие европейские страны, США, Канада, Япония и Южнная Корея (0.5-1\%).

Это про борьбу наших управлениев за сокрашение этого числа (заявленная иель: увеличение эффективности «через лучшее снабжение лучших»). В смысле уменьшения числа ученых они своей иели добились, однако если посмотреть на долю РФ в мировых иитированиях, то она самая низкая из G20.

МГ: Прежде всего отмечу, что цель «увеличение эффективности "через лучшее снабжение лучших"» вовсе не тождественна борьбе за сокращение числа ученых. Если хотели бы число ученых сократить, то речь должна была идти не о лучшем и худшем снабжении, а об увольнении худших, причем с запретом для них занимать научные должности в течение какого-то срока. Кстати, подобное в истории нашей страны было - после сессии ВАСХНИЛ 1948 г. «худшие» были выделены по их отношению (положительному) к генетике, и «самые худшие» были уволены с научных должностей ${ }^{5}$ (а «лучшим из худших» было запрещено работать по специальности, но, в принципе, разрешалось заняться какой-либо иной наукой).

Поскольку ученые вовсе не равнозначны по эффективности и значимости своей работы, то желание государства лучше снабжать именно лучших, а не худших, или хотя бы всех, представляется вполне логичным.

5 Подробности борьбы с наукой, когда государство берется за эту борьбу в реальности (а не только в воображении отдельных ученых-паникеров) заинтересованные читатели могут найти в фундаментальном труде В.Н. Сойфера [2002, с. 669-692]; там же есть ссылки и на документы. В частности, после августовской сессии академик-секретарь АН СССР Бруевич направил секретарю ЦК Шепилову документ, в котором объяснял, как АН СССР выполнила распоряжение пртии и кого из ученых уволили. Затем Бруевич просит партийные органы «дать указния... об использовании на работе вышеуказанных сотрудников». Правда, предложения о трудоустройстве касались лишь 50\% поименовнных ученых, причем докторов наук и профессоров предлагали отправить трудиться, среди прочего, в совхоз в Молдвию, в Карело-Финскую ССР, в колхозы, в пихиатрическую больницу. ЦК рассмотрело это письмо-просьбу и утвердило предложения, но только в отношении $42 \%$ ученых. Остальным грозило тунеядство (а в СССР оно было уголовно наказуемо). 
ДК: При этом показатели по финансированию науки в РФ на общем фоне вполне пристойные (1.1\% ВВПГ), по сравнению с ведущими странами (у которых это 1.5-3\%). Получается, что эффективность от каждого вложенного рубля очень низкая (что и отражено на соответствующих графиках, см. отчет). T.e число ученых уменьшили, финансирование (немного) увеличили, а на выходе - только рост числа публикаций на $40 \%$ за 9 лет с 2008 по 2018 г. Казалось бы, $40 \%$ это неплохо, но на фоне других стран выглядит довольно убого. Чтобы корректно сравнивать, надо отнести РФ $к$ той группе, $\kappa$ которой она принадлежит. Но вот тут возникает проблема. Если сравнивать ее с «самыми ведущими экономиками мира, которые ужсе практически исчерпали потенциал своего развития) (это США, Япония, Франция, Германия, Италия, Великобритания - их индивидуальные темпы прироста по публикациям за 9 лет составляют от 10 до 30\%), то тут мы их конечно обгоняем по вполне понятной причине (те ужсе и так держат предельный темп, а у нас для роста еще есть потенциал). Но поскольку все же мы явно не из их лагеря (хотя наши управители и убеждают нас в обратном), то сравнивать попробуем со «странами G20, которые еще не исчерпали потенциала своего развития». Тут мы далеко позади. Если посчитать, то окажется, что прирост числа их публикаций за те же 9 лет составляет от 100 до 800\%. Так что по количественным показателям мы находимся где-то в промежнности между развитыми и развивающимися странами G2O. При этом доля РФ от общего вала публикаций $G 20$ за 9 лет составляет лишь около $2 \%$, что явно не может существенно влиять на мировое развитие. Качество публикаций можно оценить по показателю участия страны в $10 \%$ самых

6 ДК: В 1959 г., кстати, судя по отчетам ЦРУ, у нас и США было поровну: 2.5\%, что и давало нам преимущество в науке, которое признавали тогда американские аналитики (см. https://zen.yandex.ru/ media/nauka/chto-dumali-v-ssha-o-nauke-v-sssr-izdoklada-cru-5ef4d2c21000ae4a2c0d1dff)

МГ: Оперирование в данной связи \% ВВП мне всегда казалось странным. Ведь за какой-либо прибор мы платим не проценты от ВВП, а рубли, доллары или евро, т.е. важнее анализировать не относительные, а абсолютные показатели. Действительно, пусть например государство Тувалу будет тратить «на науку» даже не $3 \%$ ВВП, как «ведущие страны», а еще больше, скажем, $4 \%$. Обгонит ли тувалинская наука хотя бы российскую, не говоря уже об американской? Вряд ли, ибо в абсолютном выражении эти 4\% равны всего лишь \$2 млн. (в 2019 г.), т.е. если не ошибаюсь, на них можно купить хорошие спектрометр с квадрупольным детектором - 1 шт. и электронный микроскоп - тоже лишь 1 шт. цитируемых мировых публикащий. Вот тут мы уверенно стоим на последнем месте. Похожей на нас по большинству показателей страной G20 является только Турция, но даже у нее показатель цитируемости все же несколько выше.

Так что можнно с уверенностью заключить, что политика нашего правительства в области науки полностью провалилась. Если задать нашим чиновникам от науки сакраментальный вопрос «почему?», то готов голову отдать на отсечение, что мы услышим длинную речь, общий смысл которой будет $в$ том, что им достались «плохие ученые» (неправильные пчелы). Чиновники просто последнее отдают ради повышения эффективности, а неблагодарные и ленивые ученые все никак не перестроятся, упираются и не хотят работать, хоть ты тресни, хотя на них беспрерывно льется золотой дождь (дождь, правда, странный какой-то, на одних льет, на других и капли не попадает). Что будет делать ответственный чиновник в такой ситуации? Есть два варианта зависящие от того, насколько он сам контролируется со стороны других чиновников. Первый вариант - (если не контролируется) прямо наврать или сказать народу полуправду о действительном положении науки; второй вариант (если контролируется) - продолжсать давить (на) ученых, как и до этого делал, но только еще сильнее. Здесь предела практически не установлено до самого «победного» кониа. Нам, конечно, как страдательной части, предпочтительней первый вариант, но боюсь, что возобладает второй, поскольку над чиновниками сидит следующий слой чиновников, которому нечего делать, кроме как контролировать нижних.

МГ: «...число ученых уменьшили, финансирование (немного) увеличили...». Ну нельзя же так неконкретно... Ну и что, что уменьшили число ученых? На сколько уменьшили? Достаточно ли этого? Давайте, все-таки, оперировать строгими количественными показателями. Воспользуюсь примером, который приводил акад. Эрик Михайлович Галимов.

Во Франции действует Центр национальных научных исследований (CNRS). Он имеет сходную с Российской академией наук структуру. Департаменты физики, химии, биологии, гуманитарных наук и т.Д. соответствуют нашим отделениям. Так же, как и РАН, Центр является государственной организацией, в состав которой входят институты. Задача CNRS - фундаментальные исследования. Годовой бюджет французского Центра составляет \$3.6 млрд., а Российской академии наук - в 3 раза меньше. 
Если штат центра - 26 тыс. человек (из них 11 тыс. научных и 14 тыс. инженерно-технических сотрудников), то у нас 107 тыс., из которых 53 тыс. научных сотрудников. Это означает, что финансирование в расчете на одного российского ученого в 12 раз меньше, чем французского. В понятие «финансирование» входит не только зарплата ученого, но и расходы на оборудование, эксперименты, содержание имущества. При этом Франция не самая богатая страна. Французские ученые с огорчением отмечают, что содержание науки у них близко к нижнему пределу диапазона финансирования науки в развитых странах [Галимов, 2012, с. 73]. Итак, может сейчас Россия в 12 раз увеличить финансирование своих ученых? Думаю, ответ очевиден: не может. Но нужно ли это? Повторю, что ученые вовсе не равнозначны по эффективности своей работы. В Приложении 1 приведен конкретный пример: почти наугад была выбрана фамилия («А-ий»,
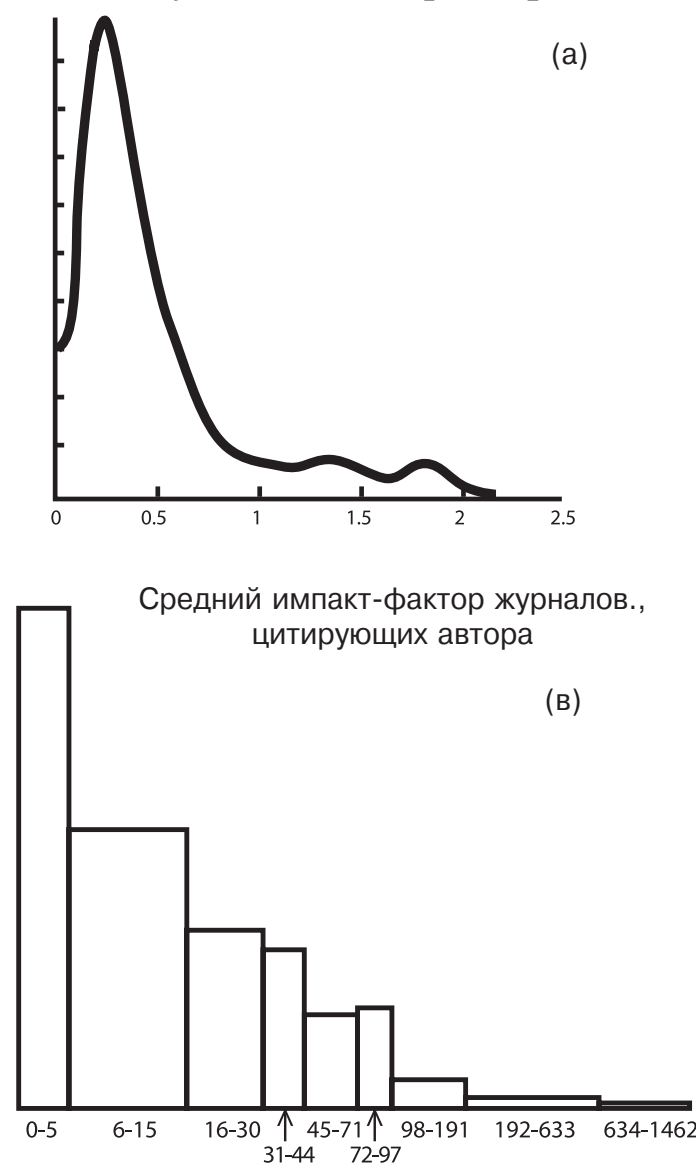

Количество ссылок
«А-ая»), и по данным РИНЦ вычислены различные наукометрические показатели для ученых, носящих эту фамилию. Всего носителей этой фамилии оказалось 53 человека. Обратите внимание: в примере акад. Галимова оказывается, что во французском аналоге ученых в 2 раза меньше, чем в нашей РАН. Отсюда возникает крамольная мысль - нужно ли нам поддерживать столько ученых? Если ранжировать рассматриваемых в Приложении 1 «А-ких», например, по количеству полученных ссылок, то окажется, что «лучшие» (наиболее цитируемые) 26 человек получили 8613 ссылок, а оставшиеся 27 человек - лишь 569 ссылок. Конечно, суммарное количество цитирований, возможно, не слишком хороший показатель, поскольку может оказаться, что получившие больше цитирований просто старше - они раньше начали публиковаться. Но на рис. 1 я привожу распределения ученых по самым разным показателям, в том числе, не зависящим от

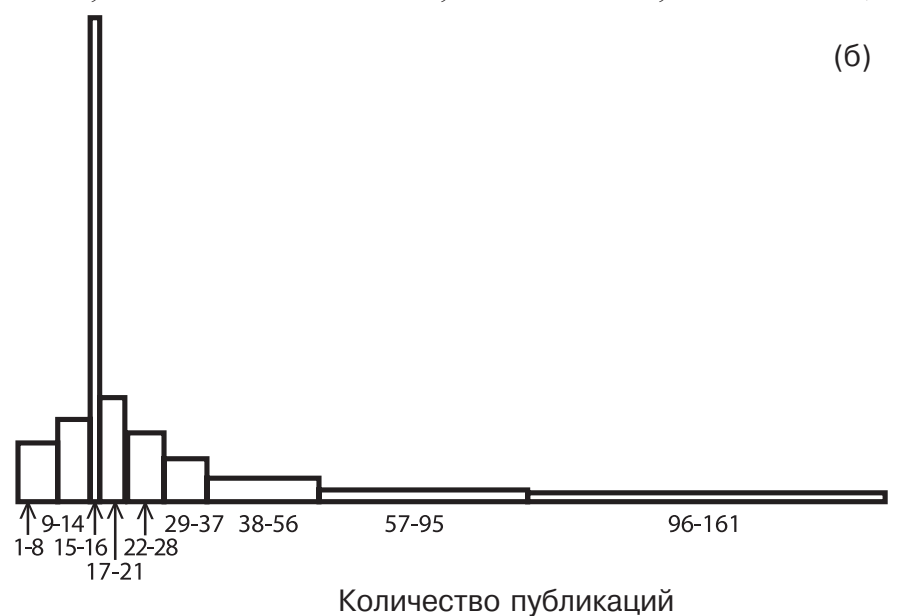

б)

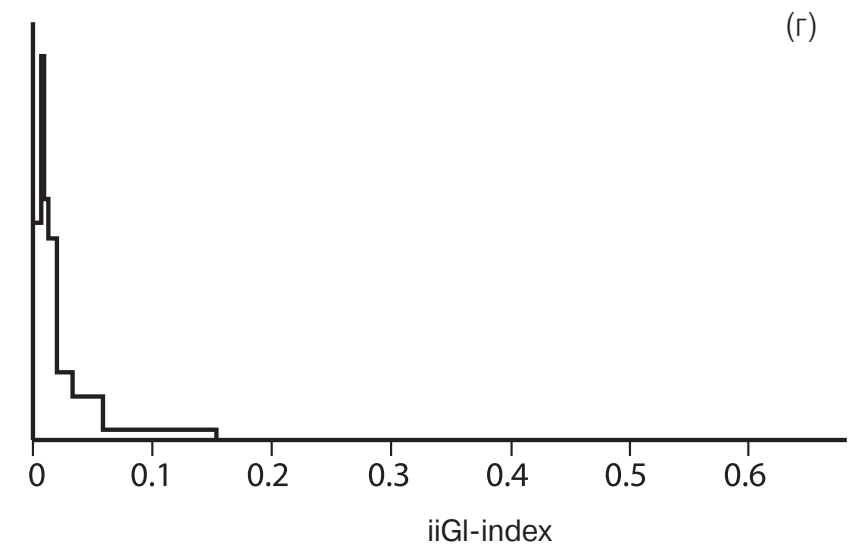

Pис. 1 Распределение ученых из табл. П1 (см. Приложение 1) по:

а) среднему импакт-фактору журналов, цитирующих их статьи;

б) количеству опубликованных ими статей;

в) суммарному количеству ссылок (масштаб оси абсцисс - логарифммический);

г) «улучшенному независимому GI-индексу» (см. определение iiGl-индекса в Приложении 1).

Для построения распределения (а) была использована стандартная функция MATLAB ksdensity, использующая так называемый «ядерный метод», а для (б)-(г) применялся метод гистограмм с интервалами равной вероятности (об этих методах см., например, [Костылев и др., 1991, с. 79; Bowman and Azzalini, 1997; Кривенок и др., 2014; Глаголев и Сабреков, 2008] и литературу там). 
возраста. Как может убедиться читатель, картина везде одинаковая - малая часть наиболее эффективных исследователей делает столько же, сколько все остальные (кстати, заканчивая пример с количеством ссылок, замечу, что 5 наиболее цитируемых ученых получили в сумме ссылок больше, чем все остальные 48 человек - 4721 против 4461). Аналогичные результаты были получены нами ранее для другой группы исследователей (сотрудников факультета почвоведения МГУ им. М.В. Ломоносова) и опубликованы в [Глаголев и Суворов, 2009]. Только малая часть публикуется в журналах, имеющих высокие значения ИФ, только малая часть опубликовала около сотни статей, только малая часть получила около 1000 ссылок на свои работы.

И еще одна, на сей раз совсем уж крамольная (в наше политкорректное время) мысль. На с. 3 цитированного ДК отчета мое внимание привлекло одно число, которое ранее не было мне известно: «среднемировой показатель доли женщин в общем числе исследователей составляет $30 \%$. А сколько в России? Если, во-первых, гендерный состав исследователей, определенный для РФ и в среднем для G20 различается; и, во-вторых, результативность научной работы зависит от пола, то, возможно, некоторые ее особенности в России получат естественное объяснение - заинтересованные читатели могут подробнее познакомиться с этим в Приложении 2 (кстати, хотя среди «А-ских» в 2 раза больше женщин, чем мужчин, но в рассмотренной выше пятерке лидеров цитируемости - лишь одна женщина, причем она занимает 5-ое место, хотя от момента первой ее публикации прошло 35 лет, тогда как средний «публикационный стаж» лидеров-мужчин на 7 лет меньше).

ДК: Что же касается «золотого дождя», то на самом деле его нет. Это следует как из ничтожных (сравнительно с западными) размеров грантов, так и зарплат. Россия среди тех же G20 по сию пору остается единственной (!) страной, где зарплата профессора (или его аналога по должнности) ниже, чем ВВП на душу населения, выраженного в ППС. Более того, она уникальна в этом отношении и в мире. Хуже ситуация разве что в некоторых бывших союзных республиках (например, Украина, Белоруссия, Таджикистан). И это дажке с учетом дополнительных доходов в виде грантов и надбавок за статьи. По моим оцен-

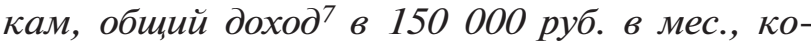
торый для этой категории можкет считаться хорошим, примерно соответствует по поку-

7 Подчеркну, что это не оклад, а общие доходы на научно-преподавательском поприще ученого в ранге профессора с учетом всех его грантов, доходов от преподавания, и других научных мест работы. пательной способности прежней ставки научного сотрудника с кандидатской степенью по тарифной сетке СССР в 1980-е годы. При этом в этой сумме собственно оклад по тарифной сетке составляет сейчас лишь около $20 \%$, а все остальное он добывает сам, чтобы не сгинуть с голоду. Если в советские времена зарплата профессора со всеми надбавками в 5-6 раз превосходила зарплату дежсурного на эскалаторе в метро, то все российские годы, по моим наблюдениям, она была ниже. Другой мой коллега (профессор МГУ) постоянно сравнивал свою зарплату с зарплатой дворника, и все никак не мог его догнать (прямо, как Ахиллес черепаху). При современной балльной системе за статьи возможнные надбавки все равно не дают возможности нормально существовать большинству ученых, разве что единицам. Подчеркну, что речь здесь идет о реальных, а не теоретически возможсных, надбавках, т.е. я здесь уже учел, согласно своему опыту, что возможно, а что нет. Отсюда распыление сил тех же ученых на добывание хлеба насущного на стороне, или уход из науки. А как уже было сказано, достаточное количество (нормально занимающихся своим делом) ученых в стране имеет ключевое значение для развития страны. Это касается и их участия в преподавании, т.е. непосредственном просвещении людей. Хороший преподаватель - это всегда ученый, и наоборот.

Кроме того, существующая сейчас в академии наук и высшей школе РФ балльная система надбавок выглядит, на мой взгляд, просто чудовищно. Распределение денег устроено так, что поневоле приходит в голову, а не лучше ли уж тогда было просто применить известный «щариковский» способ, т.е. «все взять и поделить». Перечислять уродства этой системы, порожденной высшими околонаучными чиновниками и успешно развитыми «на местах», можнно долго. Вот только некоторые их них. Фактически все российские жсурналы (как ведущие, так и проходные) приравнены к одной низшей категории.

МГ: Это совершенно не соответствует действительности! В РАН и в высшей школе действуют разные балльные системы; и даже если предположить, что во всех институтах РАН сейчас будет введена единая система, то в разных ВУЗах не только продолжают оставаться различные системы, но они иногда весьма сильно различаются даже внутри одного и того же ВУЗа (между факультетами). Чтобы разбить нелепый тезис о том, что «все российские журналы (как ведущие, так и проходные) приравнены к одной низшей категории», достаточно взглянуть на 
табл. 1. Сравним, сколько баллов получит автор, опубликовавший в 2017 г. две статьи: одну - в «Экологическом вестнике Северного Кавказа», а другую - в «Успехах химии» (5-летние IF РИНЦ, соответственно, 0.549 и 5.396). Итак, за статью в «Экологическом вестнике...» $-50 \cdot 0.549=$ 27.45 баллов, а за статью в «Успехах...» - 50·5.396 $=269.8$ балла. Разница на порядок! Как можно при этом говорить, что «все российские журналы... приравнены к одной низшей категории»!? Кстати, о «низшей». Обратите внимание, что, если бы автор опубликовался в одном из лучших журналов мира - «Nature» или «Science», относящихся по всем существующим мировым рейтингам к наивысшей категории, то на факультете почвоведения он получил бы 250 баллов (тип журнала: «Тор25\%»). Но, пренебрегая «проклятым зарубежьем» и опубликовавшись в отечественных «Успехах химии», автор получит почти 270 баллов, так что этот российский журнал относится вовсе не к низшей, а супер-высшей категории! Да и «Эко. Вестник...» формально не относится к низшей категории, как это ясно видно из табл. 1.
Предвижу запоздалые возражения ДК: «Я несколько неловко выразился, поэтому меня неправильно поняли: конечно, я имел в виду не столько высшую школу, сколько исключительно институты РАН». Это ничуть не меняет дела. И в институтах РАН различающиеся по качеству российские журналы оказываются в разных категориях, а не только в низшей.

В новой оценочной балльной системе (далее ОБаС) РАН, к низшей можно отнести журналы, входящие в перечень ВАК и более никуда - ни в «список WoS», ни в «список Scopus». Статьи в журналах этой (низшей) категории предлагалось оценивать в 0.5 балла 8 . Но если статья опубликована в российском журнале, индексируемом в Scopus, то она получит в 2 раза больше баллов. Если же она опубликована в российском журнале, переводная версия которого индексируется в WoS и входит там в 3-й квартиль, то она получит 2.7 балла (т.е. уже в 5.4 раза больше) [Кузьмин, 2020]. Однако после широкого обсуждения количестввенные характеристики балльной системы были несколько изменены, и она принята в иной

Таблица 1. Официальная система начисления бамлов за статьи научных сотруАников факультета почвовеАения МГУ*).

\begin{tabular}{|c|c|c|}
\hline Тип журнала & Характеристика статьи & Баммы \\
\hline Top $25 \%$ & Количество страниц > 2 & 250 \\
\hline Top $25 \%$ & Количество страниц $<3$ & 15 \\
\hline «Рейтинговые по почвоведению»**) & Любая статья & 100 \\
\hline Журнал из списка WoS & Количество страниц > 2 & 70 \\
\hline Журнал из списка WoS & Количество страниц и соавторов $<3$ & 10 \\
\hline Журнал из списка Scopus & Количество страниц > 2 & 70 \\
\hline Журнал из списка Scopus & Количество страниц и соавторов $<3$ & 35 \\
\hline Журнал из списка РИНЦ & Любая статья & 50·ІІРИНЦ \\
\hline Другие журналы, в т.ч. международные & Любая статья & 25 \\
\hline
\end{tabular}

\section{Примечание:}

*) данные с сайта https://istina.msu.ru/pmodel/view/58238922/;

**) т.е. «Почвоведение» или «Вестник МГУ. Сер. 17. Почвоведение».

На каждом факультете свою систему балльной оценки утверждает Ученый совет (УС). И именно он решает, идти ли в ногу с развитыми странами - относить ли большинство российских журналов к «низшей категории» (к которой они относятся в мировых рейтингах); или торить свой самобытный путь, на котором возвести на пьедестал «Успехи химии» (впрочем, это еще ничего - журнал-то, объективно говоря, весьма хороший), а за 1-страничные тезисы в «ІОР Conference Series», которые подчас и не рецензируются (поскольку редакторами являются сами сотрудницы, которые туда пишут статьи), давать 30 баллов. редакции (см. табл. 2), согласно которой разница между низшей и другими категориями еще больше. Например, если статья опубликована в журнале, индексируемом в Scopus, то она получит не в 2, а примерно в 8 раз больше баллов, чем статья в «ВАКовском» журнале.

8 Строго говоря, методика оценки более сложна - количество баллов за статью, получаемое автором, зависит не только от категории журнала, но и от количества соавторов статьи и количества аффилиаций данного автора. Для нас сейчас эти сложности не имеют значения, поэтому будем рассматривать простейший случай: статья написана одним автором, указавшим единственное место работы. 
Таблица 2. Официальная система начисления балмов в РАН за публикации научных сотруАников.

\begin{tabular}{|c|c|c|c|}
\hline \multirow{2}{*}{\multicolumn{2}{|c|}{ Публикации }} & \multicolumn{2}{|c|}{ Баммы в ОБаС } \\
\hline & & \multirow{2}{*}{$\begin{array}{c}\text { преАложенной } \\
19.7\end{array}$} & \multirow{2}{*}{$\begin{array}{c}\text { принятой } \\
20\end{array}$} \\
\hline в изданиях, индексируемых WoS Соге Collection (если & Top $25 \%$ & & \\
\hline журналу присвоен квартиль по нескольким направлениям, то & Q2 & 7.3 & 10 \\
\hline & Q3 & 2.7 & 5 \\
\hline & Q4 & 1 & 2.5 \\
\hline \multicolumn{2}{|c|}{$\begin{array}{l}\text { а) в изданиях без квартиля, но входящих в WoS Coге Collection; } \\
\text { б) в изданиях, индексируемых в Scopus, но не в WoS; } \\
\text { в) рецензируемые издания книжного формата, зарегис-трированные в } \\
\text { Российской книжной палате и рекомен-дованные к печати Ученым } \\
\text { советом организации }\end{array}$} & 1 & 1 \\
\hline \multicolumn{2}{|c|}{ в журналах из RSCI WoS, не индексируемых в Соге Collection WoS или Scopus } & 0.75 & 1 \\
\hline \multicolumn{2}{|c|}{$\begin{array}{l}\text { в журналах списка ВАК, не входящих в вышеперечисленные пункты (по } \\
\text { данным РИНЦ) }\end{array}$} & 0.5 & 0.12 \\
\hline
\end{tabular}

ДК: все области науки приведены к общему знаменателю по оценочным показателям, независимо от их специфики (есть области, где, например, просто нет или мало жмурналов WoS высших квартилей).

МГ: Должен напомнить читателям принцип выделения квартилей. Журналы сначала разделяются по областям науки, а потом делятся на квартили. Конечно, нельзя сказать, что в каждой области науки выделяется абсолютно одинаковое количество журналов, но, вообще говоря, стремятся к тому, чтобы области различались по нему не слишком сильно. И вот, что можно сказать абсолютно точно, так это то, что при таком подходе в одной области журнал с $\mathrm{IF}=2.5$ попадет в высший квартиль, а в другой - во 2-ой квартиль (если вообще не в 3-ий).

ДК: статьи, написанные сотрудником «не по теме» вообще нигде не засчитываются (вспоминаются школьные сочинения).

МГ: Я в этом не уверен. Приведу примеры из собственного опыта. При старой системе в Институте лесоведения РАН (где я имею честь работать по совместительству) УС пытался не засчитать некоторые подобные работы, например, [Глаголев и Сабреков, 2014; Сабреков и Глаголев, 2016; Глаголев и др., 2017]. Но я обращался к заместителю директора, к директору и аргументированно доказывал, что, хотя эти публикации не находятся в русле лесоведческой (или хотя бы лесоводческой) науки, они, являясь рецензируемыми статьями, тем не менее, важны для науки хоть какой-то, а подчас и смежной с лесоведением. Практически во всех случаях мне пока удавалось добиться торжества Справедливости. Посмотрим, как будет дальше - при новой балльной системе.
ДК: Число баллов за отдельные категории начисляется по принципу, просто придуманному каждой администрацией без какого-то внятного научного обоснования.

МГ: Это опять не соответствует действительности! Я неоднократно беседовал с представителями администрации, занимавшимися разработкой соответствия баллов категориям на факультете почвоведения МГУ и в Институте лесоведения РАН. Эти беседы показали мне, какая глубокая наукометрическая проработка была проведена, чтобы выбрать именно такие, а не другие баллы. К сожалению, беседы «к делу не пришьешь». Однако могу привести и одно более серьезное - письменное - доказательство: хочу обратить внимание ДК на статью [Глаголев и Лапшина, 2012], в которой частично обосновываются баллы для оценки эффективности публикаций сотрудников одного из подразделений Югорского государственного университета. Подчеркну, что статья эта была написана за несколько лет до того, как на ее основе была введена соответствующая ОБаС на кафедре ЮГУ «Динамика окружающей среды и глобальных изменений климата».

ДК: Баллы так или иначе делятся на количество соавторов (иногда корень, иногда еще

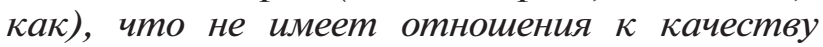
статей, но сильно бьет по доходам авторов";

9 В уже теперь классической работе [Wuchty et al., 2007] на основе анализа 20 млн. публикаций за 45 лет было однозначно показано, что научную продукцию наиболее эффективно создают большие группы авторов, а не одиночки. И за эти полвека среднее число соавторов увеличилось с 1.9 до 3.5, т.е. почти вдвое. За тот же период вдвое выросло число статей, написанных группами. Кроме того, авторы исследования обнаружили, что статьи, написанные группами, цитируются вдвое чаще (без самоцитирования), чем у одиночек. Получается, что научная политика РФ направлена против мирового тренда 
общее число баллов автора делится на число его афиллиаций (чтобы лишнего не получал). Последнее выглядит особенно цинично, если учесть, что именно министерская политика РФ по оплате приводит к тому, что люди вынуждены подрабатывать в нескольких институтах или вузах, чтобы прокормиться, а тут им фактически говорят: «Зачем мы вам будем платить, если вы и так деньги на стороне получаете?». Так я жке их именно зарабатываю, а не просто так получаю, чем же это плохо?

МГ: Нет. Какое же это зарабатывание, если за одно и то же получаешь два (а то и тричетыре) раза ${ }^{10}$ ? Мне хочется назвать это не зарабатыванием, а мошенничеством. Впрочем, мошенниками являются не ученые. По сути дела, на законных основаниях была введена мошенническая система, и государство долгое время обманывало само себя, искренне удивляясь: почему же не растет производительность научного труда. Чтобы лучше прояснить абсурдность этой системы приведу пример из сферы материального производства. Представим себе бригаду рабочих, которая работает на одном автозаводе, а на полставки в свободное время - еще и на другом. Эта бригада на своем первом заводе собрала автомобиль, получила за это зарплату, а потом (по требованию администрации второго завода) предъявила его и получила еще одну зарплату там. По отчетности будет два автомобиля, а в реальности-то он один. То же самое и с публикациями.

Напомню, что выше ДК сетовал на не слишком большой рост числа публикаций в РФ (40\% за 9 лет). А вот теперь он показал и одну из причин этого. Какой смысл российскому ученому писать 2 (а, тем более, 3 или 4) статьи, когда можно написать одну и отчитаться ими в 2 (а то и 3-4) местах? Но статья-то, в реальности, одна! Поэтому и рост количества публикаций оказывается не на $80 \%$ (120\%, 160\%), а только на $40 \%$.

ДК: Теперь об общем числе публикаций. $Я$ сейчас пишу не меньше 5-6 статей в год. Однако, если посчитать, сколько мне их надо, чтобы сводить концы с концами, то оказывается, что этого мало. Гранты требуют, чтобы ты ссылался в статьях только на них.

МГ: Опять не соответствует действительности. Да, есть такие, которые требуют ссылаться только на них. А другие допускают написание одной статьи по нескольким проектам (но при этом иногда надо указать - какая часть рабо-

${ }^{10}$ Причем один автор, работающий только в одном месте, получал надбавку за статью один раз, а другой, работающий в трех местах, за ту же самую статью получал три раза. ты каким грантом финансировалась). Чтобы не быть голословным, сошлюсь на несколько работ, в которых авторы выразили благодарность сразу двум финансировавшим их грантам: [Terentieva et al., 2016; Косых и др., 2017; Kapitonova and Aksarina, 2019; Vasilev et al., 2019].

ДК: Поскольку гранты у нас маленькие, то их надо тоже не один, а 3-4 (можно подумать, что их просто так раздают). По гостеме, по которой нам платят наши базовые нищенские зарплаты, ты тоже должен выдавать «норму», чтобы получить свою пайку. В итоге я насчитал, что мне надо производить не меньше 10 статей в год. А после введения деления на количество афиллиаций, мне еще надо писать не менее 3 статей дополнительно для моего второго места работы. И везде требуют статьи из высших квартилей, да еще WoS. Но есть два фактора, которые жестко ограничивают здесь наши возможности: время $=24$ часам в сутки, и закон снижения качества при переходе в количество. Чиновники же, видимо, понимают написание учеными статей буквально, за пару часов, как это обычно делают журналисты, т.е. «на коленке». Иными словами, в чем проблема: взял компьютер и набрал сколько нужно слов, а если слов не хватает, то скопировал откуда-нибудь из интернета. Вот и все, дальше осталось только отправить все это добро в журнал, входящий в группу «Тор $25 \% »$, где его в ту же минуту и опубликуют. И автоматические проверщики грамматики для вас изобрели, и он-лайн переводчики, так какого рожна вам еще надо? Ах у вас ее не приняли, так значит плохо написали, а такие ученые нам не нужны. Следующий!

МГ: К счастью, сейчас именно такой процесс в России и идет. Ученые, не способные работать на мировом уровне, постепенно сходят с арены, уступая свое место более молодым и активным (в частности, способным публиковаться в Тор $25 \%)$. Но, к сожалению, процесс этот идет довольно медленно. Как и ДК, буду судить по себе. Мне совершенно ясно, что занимаюсь наукой практически в свое удовольствие, никогда не напрягаюсь по поводу того, что вот срочно надо написать какую-то статью, чтобы сводить концы с концами. За 5 лет - с 2015 по 2019 г. включительно - был соавтором 37 статей в научных журналах, но первым автором ${ }^{11}$ - лишь в 11 (причем только 3 из этих 11 входят в WoS и Scopus). В общем-то, при нормальной ОБаС таких как я надо гнать из научных учреждений поганой метлой, что-

11 Учитывая, что по данным РИНЦ в «моих» статьях в среднем 4.2 автора, то лично я за эти 5 лет написал как бы $37 / 4.2 \approx 8.8$ статьи. 
бы освобождали дорогу молодым, способным работать на международном уровне. Так вот, повторю, совершенно не напрягаясь, я, тем не менее, каким-то чудом в ИСТИНЕ имею на сегодня (июль 2020 г.) 4352 балла' ${ }^{12}$, что в 2.7 раза превышает медианное значение по моей должности (старший научный сотрудник). Более того, это в 1.7 раза больше медианного значения по должности ведущего научного сотрудника (на нашем факультете в.н.с. - самая высокая научная должность, ибо главных научных сотрудников вообще нет).

ДК: Несколько слов про действительный процесс написания статьи в хороший западный журнал, о чем все наши прекрасно и так знают, поэтому этот абзаи, предназначен исключительно для случайно забредшего сюда чиновника. Во-первых, чаще всего в нашей области на это уходит 1.5-2 года, а иногда и больше. Обычно это связано с процессом рецензирования, который на западе весьма отличается от нашего. Иногда приходится только очередь на рецензирование ждать по полгода. Сбор полевого материала занимает часто несколько лет, и стоит 1-2 миллиона рублей. Лабораторные анализы требуют еще пару миллионов. Если нет необходимых приборов, то выкладывайте еще не меньше 4-6 млн руб. (меньше серьезные научные приборы сейчас не стоят). За саму публикацию с вас тоже в платном журнале возьмут не меньше 2 тыс. евро, за квалифицированный перевод - еще около 500 евро. Говорю все это исключительно на своем опыте работы в области глобальной экологии, и по своим цифрам. Понятно, что научные статьи идут обычно не «одна за одной», а параллельно сразу несколько, да и готовит их всегда целый коллектив (это $\kappa$ вопросу о делении баллов на число соавторов), но это оббясняет, почему в один год у автора часто выходит много статей, а в следующий может не выйти ни одной. Наша же система планирования требует точно знать: сколько ты статей опубликуешь в данный год, и никакого превышения плана тебе не зачтут, зато за недовыполнение строго спросят.

МГ: Почти со всем этим я согласен. Но разве во всем мире ученые работают как-то иначе? Правда, по своему опыту скажу, что материал

${ }^{12}$ Справедливости ради надо сказать, что ИСТИНА начисляет баллы не только за публикации, но и за другие виды деятельности. Однако если выделить только «публикационные» баллы, то их все равно окажется довольно много - 2918, т.е. все равно больше, чем нужно на моей должности. на статью в хороший западный журнал можно собрать и за один полевой сезон. А вот очередь на рецензирование (кстати, в зависимости от журнала, она бывает и существенно меньше, чем полгода) - разве она какая-то отдельная для россиян, а иностранцы идут без очереди? И разве сбор полевого материала стоит для иностранцев меньше? Или лабораторные анализы существенно дешевле? Или публикация в журнале? Нет, все справедливо, россиян никто никак не ущемляет. А эти 2 млн. на сбор полевого материала и 2 млн. на лабораторные анализы вкупе с платой за планируемую публикацию нужно (как это и делают во всем цивилизованном мире) заложить заранее в грант.

Кстати, о подготовке статьи целым коллективом. Да, хорошую статью в современной науке готовит именно коллектив. Но в реальности каждый соавтор вносит совершенно разный вклад. Обычно есть кто-то, кто берет на себя основное написание статьи (он будет первым автором), а остальные соавторы ему помогают - пишут свои небольшие разделы, принимают участие в общих обсуждениях структуры статьи и отдельных ее положений, оказывают какую-то техническую помощь, например, в оформлении рисунков или в статистических расчетах и т.п. На основе опыта нашего микроколлектива могу сказать следующее: поскольку максимально загружен только один - первый - автор статьи, то второй (третий, четвертый и т.д.) могут в это же самое время писать в качестве первого автора другие статьи, пригласив всех остальных членов коллектива в эти статьи в качестве соавторов. Если принять, что статья пишется примерно год, то через год у всех членов коллектива будет не одна статья на всех, а столько статей, сколько активных членов в этом коллективе (но только в какой-то одной статье каждый будет первым автором, а во всех остальных статьях - вторым или третьим и т.д.). Разумеется, так поступает не один лишь наш коллектив, а, смею предположить, любой активно работающий научный микроколлектив. Например, в 2019 г. А.А. Вяйзя, М.В. Киселев и Е.А. Дюкарев опубликовали работу [Вяйзя и др., 2019]. Но в том же году опубликованы статьи за первым авторством М.В. Киселева и Е.А. Дюкарева: [Киселев и др., 2019; Dyukarev et al., 2019], соавторами которых были, соответственно, Е.А. Дюкарев, а также М.В. Киселев и А.А. Вяйзя.

ДК: Что бы предложил нашим управленцам я, рядовой ученый, для улучшения ситуации, если б был «султан»? При этом будем исходить из реальности, а не «идеального мира», в котором в первую очередь просто 
следовало бы резко ограничить сам аппарат и функции Минобрнауки РФ. Поэтому воспримем последнее как неизбежное зло и предположим, что наша иель совпадает $c$ заявленной иелью чиновников, т.е. повысить эффективность российской науки, главным критерием чего является уровень публикаций. Вот что бы я сделал:

1. Наполнил бы тарифную сетку в науке не условно-базовыми, а реальными зарплатами, как это собственно и было во времена СССР. Для этого даже достаточно тех средств, которые институты сейчас получают по своей категории. Сетка должна индексироваться раз в пять лет с учетом инфляции. Оиеночно это увеличит ставки в 3-4 раза.

2. Надбавки за ученые степени должны быть установлены до уровня 50\% от ставки тарифной сетки. При существующей системе почти убивается интерес $\kappa$ защитам ученых степеней, поскольку надбавки за них даются на короткий период, или сами выплаты ничтожны.

3. Следует отменить дискриминационную балльную систему по отношению к ведушим российским журналам, как это сейчас делается. Это убивает отечественные жсурналы и отнимает у них даже потенциальную возможность выдержать конкуренцию на мировом уровне.

4. Хотя существуюшая балльная система должна быть, безусловно, отменена, но возможность надбавок по итогам года или за отдельные публикации и другие достижения должна оставаться наряду с тарифной системой. Это должна определять администрация института вместе с научной экспертной комиссией, состоящей из представителей всех отделов.

5. Размеры «медианного» научного гранта в РФ должны быть увеличены на порядок. Иначе создается ситуация, когда наряду с почти единичными т.н. мегагрантами (на самом деле это просто размер нормальных по международным меркам грантов) существует много мелких, на которые давно уже ничего толком ни сделать, ни купить - нельзя (пример: РФФИ и РНФ). Увеличение медианы не потребует даже увеличения фонда, он просто равномернее перераспределится. Если сейчас медиана находится, по моей экспертной оценке, около 2 млн., то после этого она должна стать порядка 15 млн. Хотя и увеличить сами фонды следовало бы как минимум вдвое. Ограничить драконовские требования по публикациям, которые существуют в ряде фондов (особенно, этим славится РНФ, который выдвигает несоразмерные требования, по сравнению с весьма скромным количеством выдаваемых средств).

6. Ввести мораторий на изменения системы оплаты труда ученых хотя бы на ближайшие 5 лет. Дайте людям просто спокойно nоработать.

7. Прекратить политику, стимулируюшую администрацию $к$ сокращению ставок или на ограничение перемещения сотрудников по тарифной сетке, особенно молодых. При этом оставить пороговые возрастные ограничения для ученых в иелом и администрации.

8. Убрать всю ежкегодную отчетность по гостемам, как бессмысленно отнимаюшую время. Оставить только 5-летние отчеты. Убрать требования о ссылках в публикациях на госзадания, или разрешить вставлять неограниченное число ссылок как на гранты, так и на госзадание, если публикации соответствуют их тематике.

МГ: Мне непонятно предложение (1). Якобы средств, которые институты сейчас получают по своей категории, достаточно для увеличения ставок в 3-4 раза. А сейчас куда эти средства деваются? На мой взгляд, средств у многих институтов недостаточно даже для обеспечения современных небольших ставок, поэтому директора таких институтов вынуждены просить сотрудников переходить на меньшую долю ставки.

А есть ли у меня какие-то предложения по этому П. 1? Да. И довольно радикальные. Предоставить УС институтов полную свободу в отношении количества ставок. Институт должен просто получать план работ от РАН (или подавать свой план, который РАН утверждает) и финансирование на эти работы плюс гранты, получаемые сотрудниками в инициативном индивидуальном порядке. А сколько нужно для этого сотрудников, как распределять между ними зарплаты - это уже пусть УС решает сам совершенно свободно. При этом у каких-то сотрудников зарплата как раз и возрастет в 3-4 раза, а у каких-то - упадет и, возможно, они наконец-то уйдут с насиженных мест, на которых много лет ничего не делали. Но при этом важно вернуться к системе, действовавшей в начале «Ельцинских» времен, когда директора институтов избирались именно коллективом института. Заведующих лабораториями или отделами также необходимо избирать коллективом соответствующей лаборатории или отдела; наконец, необходимо разрешить совершенно свободный переход любого сотрудника между лабораториями (разумеется, при согласии коллектива той лаборатории, куда 
он собирается переходить). Необходимо реально задействовать уже существующую контрактную систему, которая пока действует только на бумаге. Уже сейчас, формально, мы работаем по срочным (например, 5-летним) контрактам. Но по истечении срока контракта, даже если сотрудник почти ничего не делал, и отчитываться ему нечем, часто под любым предлогом ему стараются продлить контракт, причем, желательно, без понижения в должности.

П. 2 (надбавки за степени). Да зачем они вообще нужны? Человек защитил работу, иногда весьма слабую, никакого значения для развития науки не имеющую, иногда - совершенно абсурдную, совершенно неправильную... И он должен всю жизнь за это получать от государства деньги? С какой стати? Если диссертация хороша, то зашитивший ее получит свои бонусы иным образом, например, написанные на ее основе статьи будут опубликованы в лучших журналах и принесут ему множество баллов (которые трансформируются в надбавки к зарплате); или диссертантом будут получены какие-то патенты на изобретения, которые потом принесут ему дивиденды; или он будет приглашен на какую-то высокую должность... В ответ на это мне приходилось слышать такой «аргумент»: существующая система защиты диссертаций подразумевает, что любой сомневающийся в качестве работы имеет возможность выступить против присуждения степени автору не имеющей значения или вообще неправильной работы. Да, имеет такую возможность. А многие ли пользуются ею? И если пользуются, то часто ли это влияет на результат - присуждение степени? В любом случае очевидно, что какая-то часть откровенно слабых и никчемных диссертаций защищается и будет защищаться (а их авторы будут получать научные степени). Если, как предлагает ДК, ввести надбавки за степени, то такие кандидаты и доктора будут просто «доить» государство многие годы, практически ничего не давая взамен. Впрочем, пока мне тут нет смысла «ломать копья», ибо, насколько я знаю, надбавки собственно за степень в России уже давно отменены. Ныне они включены в оклад по конкретной должности. И если некоего доктора наук берут на должность м.н.с., то никакой «докторской» надбавки он получать не будет. И правильно! Что же это за доктор, если он может работать только младшим научным сотрудником?

С п. 3 («отменить дискриминационную балльную систему по отношению к ведушим российским журналам») я, разумеется, абсолютно не согласен (я бы даже сказал: дважды не согласен - ни с тем, что она дискриминационная, ни с тем, что ее следует отменить). Ее следует развивать, совершенствовать, но ни в коем случае не отменять. Вообще, надо четко понимать, что система эта дискриминирует... как раз не ведущие российские, а подавляющее большинство иностранных журналов (сейчас я говорю не про местечковую ИСТИНу, принятую в МГУ, а про ОБаС РАН). Возьмем, почти наугад несколько уважаемых иностранных журналов, напримep, «Acta Pharmaceutica Hungarica», «American Journal of Agricultural and Biological Science» и «Asian Journal of Biochemistry». Они не входят ни в Top25\%, ни в WoS, ни даже в «список BAK», а из Scopus только что были с позором изгнаны, так что теперь не входят и туда, в общем - сейчас никуда не входят. Следовательно эти журналы в ОБаС РАН не получат вообще ничего. А Вот «ВЕСТНИК ВОРОНЕЖСКОГО ГОСУДАРСТВЕННОГО УНИВЕРСИТЕТА. СЕРИЯ: ХИМИЯ. БИОЛОГИЯ. ФАРМАЦИЯ» ПОЛУЧИТ 0.12 балла, поскольку он входит хотя бы в «список ВАК». Причем последний журнал вряд ли можно признать ведущим российским журналом ${ }^{13}$. Если же мы возьмем действительно ведущие российские журналы, то, как правило, они окажутся входящими не только в «список ВАК», но часто и в 4-ый, а то и 3-ий квартиль $\mathrm{WoS}$, поэтому получат существенно больше баллов - см. табл. 2.

Здесь же хочу обратить внимание читателей, что не наличие, а именно отсутствие балльной системы убивало российские журналы и лишало их потенциальной возможности выдержать конкуренцию на мировом уровне. Действительно, зачем им было заботиться о качестве статей, если их никто никакими баллами оценивать не будет, если хоть какие-то статьи в них все равно будут поданы (ведь аспирантам надо к защите диссертации иметь опубликованные научные труды). Не могу не упомянуть о том, как иногда решался вопрос с подпиской. Когда в проклятые советские времена я был студентом факультета почвоведения, нам (всем студентам) просто велели подписаться на «Вестник МГУ. Сер. 17. Почвоведение». Кстати, этот журнал - хороший пример для исследования. Ведь для него, фактически, балльная система сейчас не существует, ибо, как видно из табл. 1, в ИСТИНЕ, в которой оцениваются достижения сотрудников факультета, ему присваивается 100 баллов, что в 1.4 раза

${ }^{13}$ Наукометрические показатели этого журнала - весьма низкие: 2-летний и 5-летний ИФ в 2019 г. составляют, соответственно, 0.239 и 0.276 , а по ядру РИНЦ - лишь 0.081 и 0.093. Причем, поскольку коэффициент авторского самоцитирования данного журнала равен $55.4 \%$, то получается, что более половины импакт-фактора обеспечивается тем, что авторы сами цитируют свои статьи. Следовательно, лишь 1 из 10 опубликованных статей получает 1 независимую ссылку, вызывая, таким образом, интерес у читателей (а не только у своих же собственных авторов). 
больше, чем можно получить, если опубликовать статью в журнале из 2-го квартиля WoS. Авторами рассматриваемого журнала как раз и являются чаще всего сотрудники и аспиранты факультета почвоведения МГУ, т.е. у них есть прямая заинтересованность в том, чтобы писать туда статьи - ведь они получат 100 баллов, почти не напрягаясь. В результате, являясь журналом одного из ведущих ВУЗов России, указанный «Вестник» не входит ни в WoS, ни в Scopus.

И еще один аргумент. Ведь некоторая балльная система действует уже многие годы. Что, ведущие российские журналы она убила? Напротив! Журналы стали бороться за свой международный рейтинг и многие преуспели в этом. Например, впервые в истории, в 2018 г. IF-WoS журнала «Микробиология» превысил 1 (а в 1995 г. составлял жалкие 0.287); в 2019 г. превысил 1 и IF-WoS журнала «Почвоведение» ${ }^{14}$ (а еще лет 15 назад он колебался между 0.03 и 0.18 ).

По п. 4 могу сказать, что ДК «ломится в открытую дверь» - сейчас именно так и есть: надбавки по итогам года или за отдельные публикации и другие достижения (система ПРНД) остаются, и их определяет администрация института вместе с УС. Свыше спушена система балльной оценки не отдельных сотрудников, а института. Это я должен особенно подчеркнуть, поскольку мне кажется, что здесь есть непонимание у ДК (и, вероятно, оно может быть у некоторых читателей). Деятельность института РАН оценивается при помощи ОБаС РАН. А деятельность каждого сотрудника института оценивается при помощи ПРНД, и именно в соответствии с этой оценкой (а не ОБаС!) он может получить надбавку. Например, буквально только что в Институте лесоведения РАН прошло заседание УС, на котором было разъяснено, как будет начисляться ПРНД в Институте в связи с введением новой ОБаС РАН. Ответственными руководителями (зав. сектором научного и образовательного обеспечения к.б.н. М.В. Смагиной и бывшим ${ }^{15}$ директором д.б.н. А.А. Сириным) было разъяснено, что сотрудникам баллы будут начисляться не только за статьи, учитываемые в ОБаС (см. выше табл. 2), но вообще за любые статьи, имеющие DOI, а также за доклады на конференциях, хотя, конечно, балл за эти малозначительные достижения будет несколько меньше минимального балла ОБаС РАН, т.е. меньше, чем 0.12 .

С п. 5 я согласен. Размеры российских грантов, действительно, не слишком велики и не всегда позволяют обеспечить исследование на мировом

\footnotetext{
14 Разумеется, ИФ рассчитывается для переводных версий отечественных журналов.

${ }^{15}$ А возможно - и будущим. На момент сдачи статьи в верстку это еще не известно.
}

уровне. Однако пропорционально увеличению размера грантов следует постепенно усиливать и требования к грантополучателям, тоже постепенно выводя их на международный уровень.

Требование п. 6 противоречит самой идее введения балльных систем. Они вводились именно для того, чтобы оперативно управлять научной деятельностью. Например, пусть в каком-то институте относительно мало публикаций в журналах из списка WoS (хотя бы и российских), а достаточное количество баллов сотрудники набирают за счет огромного количества статей в никем не читаемых и ни в какие WoS и Scopus не входящих региональных журналах. Если будет введен предлагаемый ДК мораторий, то такая ситуация сохранится в течение 5 лет. Разве это хорошо?

С п. 7 я частично согласен. Но и какие-либо возрастные ограничения я бы убрал. Все должно определяться результативностью сотрудника. Если какой-то 80-летний старец продолжает активно работать, набирает баллов в 2 раза больше, чем молодые изнеженные лентяи, то зачем же его изгонять с занимаемой должности? ${ }^{16}$

Наконец, с п. 8 я отчасти согласен. Однако допускаю, что по каким-то особо важным темам госзадания государство захочет быть в курсе дела ежегодно. Ну, что ж, на это, в конце концов, оно имеет полное право. Если институту государством предлагается какая-то исследовательская тематика, то ведь условия отчетности известны заранее. И если институт не устраивает то, что отчитываться придется ежегодно, то он может от данной темы отказаться. Государство либо сумеет найти какой-

\footnotetext{
16 Более того, считаю возрастные ограничения не только вредными по смыслу, но и юридически преступными - антиконституционными. Действительно, вспомним статью 19 Конституции РФ. «...Государство гарантирует равенство прав и свобод человека и гражданина независимо от пола, расы, национальности, языка, происхождения, имущественного и должностного положения, места жительства, отношения к религии, убеждений, принадлежности к общественным объединениям, а также других обстоятельств...». Суть этой статьи, как я ее понимаю, состоит в том, что все граждане имеют одинаковые права. Но вот получается, что если тебе, например, 85 лет, то прав у тебя меньше, чем у 40-летнего, в частности, ты не можешь руководить лабораторией. Конечно, критиканы могут возразить: «Почему ст. 19 формулируется так? Не лучше ли было бы сказать “а также любых других обстоятельств"?». Но такая формулировка вошла бы в противоречие с другими статьями Конституции, которые, как раз-таки, и определяют - какие уникальные обстоятельства (например, зключение под стражу по приговору суда) могут приводить к лишению прав (и каких конкретно прав). Права «преуспевших в годах» (как принято называть почтенных старцев в США [Воробьев, 1993]) она не ограничивает.
} 
то другой институт, который с таким условием согласится, либо пересмотрит свое требование и даже по этой теме разрешит отчитываться раз в 2 года или даже раз в 5 лет.

ДК: Возможно, я о чем-то забыл упомянуть, но, в любом случае, главное направление необходимых на мой взгляд реформ - прекратить навязанное нам «нищебродство» и начать наконеи платить людям ИХ деньги за их работу. Или хотя бы некоторое время не мешать. И вы удивитесь, насколько вырастет научная производительность труда. Яркий пример тому - продолжсаюаяся сейчас пандемия. В условиях, когда чиновники вдруг оказались не у дел, и перестали дергать всех на совещания и с прочей ерундой, люди, наконеи, получили возмохсность что-то написать и над чем-то подумать. Однако, думаю, если через год по этой причине вдруг возникнет всплеск российской публикационной активности, чиновники все это немедленно припишут успеху своей многолетней кропотливой работы. Впрочем, как мы все прекрасно понимаем, все эти проблемные ноги растут из одного и того же места, и пока это место существует - ничего не изменится.

\section{AKחIOUEHARE}

Вопросы организации и развития науки обсуждаются учёными перманентно, и вряд ли в истории постсоветской России был хотя бы какой-то момент, когда всех всё устраивало. В 90-ые годы XX века было больше организационной свободы, но с мизерными зарплатами и практически без грантов. В новом тысячелетии ситуация постепенно изменялась, появились крупные отечественные фонды грантовой поддержки (сначала РФФИ, затем РНФ), проведена реформа РАН, введена количественная балльная система оценки научной эффективности на основе созданных электронных баз данных и библиотек. Последнее отражает объективную тенденцию функционирования государственного аппарата в последние годы - введение количественных показателей эффективности хозяйственной и управленческой деятельности на всех уровнях. Для научного сообщества повернуть вспять этот тренд утопия, так как оно не имеет необходимого для этого влияния на принимаемые решения. Более прагматичным стремлением со стороны учёных будет попытка выстроить рациональную и гибкую систему оценки собственного труда. Этому, главным образом, и посвящена настоящая дискуссия. Кратко рассмотрим сходства и различия в позициях дискутирующих.
Тезис о недофинансировании отечественной науки разделяется обоими участниками дискуссии, хотя некоторые обстоятельства рассматриваются ими по-разному. Разногласия вызвало правило учёта числа аффилиаций в статьях при начислении за них баллов. Позиция МГ здесь кажется более глубокой: это правило лишь компенсирует ситуацию, когда учёные отчитываются одним и тем же в разных организациях. Понятно, что исходно это вызвано тем, что зарплата на основной работе не соответствует желаемой. Однако было бы справедливо, если бы труд учёного оценивался по его научным заслугам, а не в соответствии с количеством мест работы, на которые ему удалось устроиться, в том числе благодаря личным знакомствам. Человек всегда ищет, где лучше, и даже если зарплату на основном месте работы поднимут в разы, никто сам от совместительства не откажется. Поэтому наличие такого компенсирующего делителя баллов можно считать оправданным.

Методики оценки важны для учёных не только с точки зрения «Хлеба насущного». Они затрагивают и самооценку исследователей, рассматривают их место в иерархии относительно коллег, что для многих чрезвычайно чувствительно. Таким образом, формируется один из ключевых для участников дискуссии вопросов - о правилах игры: насколько они должны быть общими, а насколько должны регулироваться на уровне администраций институтов и университетов. Здесь участники дискуссии также имеют сходные позиции, предлагая предоставлять научным организациям автономию разной степени по регулированию системы распределения баллов. Однако МГ приводит ряд примеров, где «перегибы на местах» привели к абсурдной ситуации, когда полноценная статья в журнале из 2-ого квартиля в WoS «стоит» в полтора раза меньше баллов, чем статья в русскоязычном журнале, который не входит ни в WoS, ни в Scopus. O такого рода волюнтаризме предупреждает и ДК. Именно замыкание учёных на конкретных журналах, большая часть редколлегии которых, как правило, представляет организацию, «премирующую» публикации в этих журналах, способствует провинциализации отечественной науки, варке в собственном соку. Таким образом, учёные годами могут публиковать одно и то же в одних и тех же «своих» журналах с одними и теми же рецензиями, не встречая никакой критики и спокойно зарабатывая любые баллы. Способ борьбы с этим есть только один: государство должно навязывать единую систему оценки статей, принятую во всём мире, если хочет, чтобы именно статей мирового уровня 
в России писалось больше. Ради достижения этой цели и разрабатывалась ОБаС. Вероятно, ближайшее десятилетие будет посвящено выработке правил, которые, так или иначе, учтут интересы всех заинтересованных сторон.

Дискуссия о правилах игры тесно переплетена с дискуссией о судьбе отечественных научных журналов, поскольку большинство российских учёных продолжает в них публиковаться. Предложенная система ОБаС действительно оценивает публикации в них невысоко, но не потому, что они русские, а потому, что они редко поднимаются выше 4-ого квартиля WoS. Участники дискуссии расходятся во мнении относительно этого вопроса: ДК предлагает отменить балльную систему по отношению к ним, МГ - сохранить и развивать. Примеров погибших журналов ДК не приводит, а МГ даёт примеры успешно развивающихся журналов, в которых не стесняются публиковаться и зарубежные авторы. Жалобы на низкую скорость публикации, большое количество необходимой для подачи документации, ангажированность рецензирования в отечественных журналах раздаются давно, так что какие-то стимулы для развития (которое, как видим, вполне возможно в нынешних реалиях) им определённо нужны. Во всём мире локальные переводные журналы уступают по импакт-фактору англоязычным журналам-лидерам, однако публиковаться в них не перестают, поскольку на родном языке это сделать проще, требования - ниже, рецензирование лояльнее. Выделяя отечественные журналы из балльной системы, мы опять-таки усиливаем провинциализацию нашей науки. Здесь также необходим компромисс, поиск которого уже идёт: «стоимость» журналов 4-ого квартиля WoS, куда входят большинство переводных версий русскоязычных журналов, которые вообще есть в WoS, выросла после внесения изменений в исходно предложенную ОБаС [Кузьмин, 2020]. Например, до внесения изменений статья в журнале 4-ого квартиля WoS оценивалась в 19.7 раз ниже статьи в журнале 1-ого квартиля, а после изменений - лишь в 8 раз.

Участники дискуссии разделяют мнение о необходимости отмены т.н. госзаданий. Идея формулирования неких персональных государственных заданий, на которые не выделяется никаких целевых средств, кажется исключительно бюрократической и имеющей весьма отдалённое отношение к науке. Нельзя не согласиться с МГ, что для организаций, которые на самом деле выполняют конкретные задания государства, важно видеть отчётность регулярно, но это касается, главным образом, тех, кто выполняет государственный оборонный заказ.
В этом случае, как правило, нужно произвести конкретный продукт или технологию, а значит, гораздо проще оценивать эффективность. Но в гражданской (тем более фундаментальной, тем более испытывающей проблемы с применением на практике) российской науке такие требования ведут к тому, что учёные начинают писать бессодержательные публикации исключительно ради отчётности. Бюрократическая задача такой системы понятна - привести публикационную активность в соответствие с занимаемой должностью и зарплатой. Представляется, что помогла бы её решить новация, относительно которой мнения участников дискуссии также совпали: поощрение движения исследователей внутри организации по должностной лестнице, особенного молодых. Это позволило бы осуществлять (например, в рамках контрактной системы, о которой упомянул МГ) ротацию в соответствии с эффективностью учёных и выдвигать на самые высокие ставки лучших, тем самым создало бы стимул публиковаться больше и в лучших журналах, получать гранты и т.д.

Экономические вопросы, относительно которых мнения участников дискуссии как расходятся (о зарплатах, надбавках за диссертации, моратории на изменение системы оплаты труда), так и совпадают (об увеличении размеров грантов), оценивать достаточно тяжело, если не даётся какого-то обоснования таких оценок на основе анализа бюджетов научных организаций. Не раз и не два доводилось слышать, что многие институты едва сводят концы с концами, что новые ставки получить практически невозможно, а перевод сотрудников на неполные ставки ради исполнения «майских указов» - секрет Полишинеля. В такой ситуации кратное увеличение зарплат едва ли возможно. Увеличение размеров грантов при сохранении бюджета фондов (а в условиях кризиса после пандемии они вряд ли будут расти) неизбежно приведёт к концентрации ресурсов в руках сильных лоббистов, что губительно для науки. Стремление учёных к большему финансированию понятно, но гранты не должны становиться основным источником вознаграждения труда и источником власти, подчиняющим менее влиятельных учёных более влиятельным. Их разумнее расходовать на оборудование и сами исследования. Грубо говоря, как источник оплаты труда они должны быть не «основным блюдом», а «десертом». Это снова возвращает нас к вопросу о величине ставок.

Представленная на суд читателя дискуссия чётко показывает насколько необходимы балансировка системы и проработка нюансов при организации современного научного процесса. Всеобщей «уравниловки» ни между, ни внутри научных организаций не будет из-за глобального 
тренда на цифровизацию и индивидуализацию экономики и политику государств, бюрократический аппарат которых функционирует в русле этого тренда. Фрустрация относительно созданных систем оценивания деятельности учёных и институтов, которую высказывает ДК, иллюстрирует то, как недостаточно продуманные управленческие решения или их отсутствие делают всю создаваемую конструкцию несправедливой и неэффективной в глазах учёных. Наличие самых незначительных недостатков и лазеек может превратить разумную идею в фарс, примеры чего приводятся обоими участниками дискуссии. Такими лазейками, например, являются:

- возможность устроить в институт по совместительству успешного учёного (как правило, российского, работающего за рубежом), который только своими статьями выполнит норму института по баллам (или норму гранта РНФ по статьям). При этом эффективность сотрудников на полной ставке остаётся пугающе низкой.

- возможность отчитываться индексируемыми в различных системах (в том числе, Scopus) статьями, которые публикуются в де-факто нерецензируемых журналах (таких как IOP Conference Series, где рецензирование и отбор публикаций осуществляется оргкомитетом конференции без какого-либо внешнего контроля) или в журналах, напрямую торгующих публикациями безотносительно их научного содержания.

- возможность приписывать статьям в «ручных» (то есть контролируемых ключевыми сотрудниками организации) журналах любые, сколь угодно высокие баллы, не соотносящиеся с реальным местом этого журнала в научной иерархии. Это же относится к лишённому объективных причин временному приписыванию руководством организаций высоких баллов любым видам деятельности, которыми в отчётный период отличились сотрудники, близкие к руководству.

- возможность отчитываться по грантам статьями, в реальности к этим грантам отношения не имеющими. Например, образуются схемы типа «ты мне, я - тебе», когда два разных коллектива пишут по одной статье по своим темам, но помещают в них упоминания о поддержке обоими грантами.

Таким образом, вся архитектура системы, включая и организацию научных журналов, и политику распределения ставок и грантов, и оценку эффективности работы институтов и отдельных учёных, должна быть самосогласована. Разнонаправленные изменения элементов системы по отдельности ведут к разочарованию учёных в политике государства и отечественной науке, и, как следствие, отъезду талантливой молодёжи за границу.

\section{ПРИЛОЖЕНИЕ 1: НаскоЛЬКО сИЛЬНО различаются ученые по эффективности своей работы?}

На основе данных РИНЦ проанализируем некоторую выборку ${ }^{17}$ ученых по такому показателю, как цитируемость их работ (прежде всего остановлюсь на этом показателе, т.к. ДК упомянул именно о нем) - см. табл. П1. Как видим, суммарное количество ссылок у разных исследователей варьирует в очень широких пределах: от 0 (у №№ 52 и 53) до 1462 - у № 6. Неужели кто-то будет утверждать, что тех, чьи работы оказались так важны и интересны, что набрали много сотен или вот даже почти полторы тысячи ссылок, нужно финансировать так же, как и тех, чьи работы вообще никакого отклика не получили?

Однако, справедливости ради, нужно отметить, что от опубликования исследователями №o 52 и 53 их первых статей прошло лишь 10 лет, тогда как в случае № $6-26$ лет. И хотя трудно предположить, что для статей (или авторов), которым 10 лет не хватило, чтобы хоть кто-то обратил на них внимание, что-то кардинально изменится в следующие 10-15 лет, тем не менее, отметим проблему: количество ссылок - само по себе - мало что говорит о «гениальности» автора: статьи одного получат 100 ссылок за год, другого - за 10 лет, а третьего - за 1000. К этому же типу наукометрических показателей относится и широко используемый ныне для «ранжирования» ученых индекс Хирша - он тоже представляет собой некоторую интегральную величину (являющуюся функцией распределения ссылок по статьям данного автора), ничего не говорящую о том, как быстро эта величина была достигнута. Взглянем еще раз на табл. П1 (колонка «Н»): № 50 достигла за 26 лет лишь единичного индекса Хирша, исследовательница № 31 за тот же срок достигла в три раза большего индекса Хирша, а ученый № 30 за те же 26 лет - Хирша, равного аж 9!

${ }^{17}$ В случае строгого наукометрического исследования, эта выборка должна быть случайной. Выборка, используемая в данном случае, была получена следующим образом: в нее включались все учтенные в РИНЦ исследователи, с одной и той же фамилией: мужчины с фамилией А-кий и женщины и девушки с фамилией А-кая (полностью фамилии не привожу, чтобы - по просьбе ДК - кого-нибудь ненароком не обидеть). Поскольку для обсуждаемого вопроса представляют интерес лишь «активно работающие» в настоящее время ученые, то использовалось только подмножество данной выборки, элементы которой отвечали трем условиям: i) данный исследователь зарегистрировался в eLibrary; ii) в РИНЦ имеется информация хотя бы об одной его публикации; iii) его последняя публикация, учтенная в РИНЦ, датирована не ранее чем 2017 г. (т.е. считалось, что если после 2016 г. исследователь не публиковался, то он не может считаться активно работающим в настоящее время). 
Конечно, всегда можно посмотреть - за какой срок достигнут тот или иной результат, но, на мой взгляд, удобнее сразу пользоваться индексами, учитывающими время, за которое тот или иной интегральный параметр был достигнут. Вероятно, одним из простейших индексов этой группы будет «скорость цитирования», т.е. отношение суммарного количества ссылок $\left(C_{\Sigma}\right)$ ко времени, прошедшему с момента опубликования первой работы данного автора. Однако я хотел бы сейчас обратиться к несколько более сложному индексу - Gl-index’y, введенному нами в [Глаголев и др., 2012]. Этот индекс учитывает не только $\mathrm{C}_{\Sigma}$ и интервал времени, но и то, какое количество авторов участвовало в написании статьи (кажется очевидным, что одному автору написать статью самостоятельно будет сложнее, чем вместе с 10 «славными соавторами»). Впрочем, использование Gl-index'a в течение прошедших 8 лет показало, что и у него есть слабые стороны. Во-первых, в величине $C_{\Sigma}$ суммированы и независимые ссылки на работы автора, и его собственные ссылки на свои же публикации, и ссылки его соавторов на его статьи. Как видно из табл. П1, доля цитирований соавторами $\left(\alpha_{\mathrm{sc}}\right)$ может быть, фактически, любой - от 0 у ученых №№ 20 и 33 до почти 100\% у исследовательницы № 49. Представляется очевидным, что, с точки зрения «вклада в науку», наибольшую ценность имеют именно независимые ссылки, т.е. ссылки со стороны ученых, с данным автором не связанных - не являющихся его соавторами (если кто-то совершенно «чужой» сослался на ваши работы, то, значит, они его чем-то действительно заинтересовали; а вот когда ссылается соавтор, то подсознательно он, может быть, движим просто желанием сослаться на статью, одним из авторов которой сам же и является). Поэтому при расчете Gl-index’a следовало бы выделить из $C_{\Sigma}$ только независимые ссылки, чего можно достигнуть, взяв вместо $C_{\Sigma}$, произведение $C_{\Sigma} \cdot\left(1-\alpha_{\mathrm{sc}}\right)$. А поскольку Gl-index пропорционален $C_{\Sigma}$, то, фактически, нам надо просто Gl-index домножить на $\left(1-\alpha_{\mathrm{sc}}\right)$. Индекс, вычисленный только по независимым ссылкам, обычно называют «независимым» (например, существует «независимый индекс Хирша»). Но сделаем и еще одно улучшение. Представляется очевидным, что ссылки, сделанные на вашу работу из «Nature», более значимы, чем, например, из «Экологического вестника Северного Кавказа». Т.е. нужно как-то учесть «научный вес» ссылающегося журнала. Простейшим образом это можно сделать, воспользовавшись таким показателем (имеющимся в РИНЦ), как «средневзвешенный импакт-фактор журналов, в которых были процитированы статьи» (IF). Итак, если мы домножим Gl-index на $\left(1-\alpha_{\mathrm{sc}}\right)$ и на IF, то получим новый индекс, который будем называть «улучшенный независимый Gl-index» и обозначать iiGl.

Таблица П1. Некоторые наукометрические показатели.

\begin{tabular}{|c|c|c|c|c|c|c|c|c|c|c|}
\hline \multicolumn{2}{|c|}{ ИсслеАователь } & \multicolumn{9}{|c|}{ Показатель } \\
\hline № & KOA & $P_{\Sigma}$ & $\mathrm{C}_{\Sigma}$ & $A$ & $Y_{1}$ & $Y_{\text {end }}$ & IF & $\alpha_{s c}$ & H & iiGI \\
\hline 1 & А(Ш)EA & 16 & 111 & 2.06 & 2012 & 2018 & 1.423 & 0.441 & 5 & 0.6701 \\
\hline 2 & АГА & 60 & 782 & 1.14 & 2002 & 2017 & 0.272 & 0.009 & 9 & 0.5704 \\
\hline 3 & AMC & 67 & 774 & 3.67 & 1998 & 2019 & 1.874 & 0.545 & 14 & 0.3714 \\
\hline 4 & $\mathrm{AE} \Gamma$ & 6 & 18 & 1.20 & 2014 & 2020 & 1.355 & 0.444 & 1 & 0.3139 \\
\hline 5 & А(Л)ЕЮ & 36 & 259 & 7.25 & 2007 & 2020 & 1.737 & 0.452 & 9 & 0.2012 \\
\hline 6 & $\mathrm{ABH}$ & 91 & 1462 & 6.23 & 1994 & 2020 & 0.552 & 0.191 & 14 & 0.1551 \\
\hline 7 & AAH & 54 & 98 & 7.57 & 2015 & 2019 & 0.453 & 0.541 & 5 & 0.1077 \\
\hline 8 & AAC & 9 & 7 & 1.40 & 2017 & 2019 & 0.439 & 0.571 & 1 & 0.1046 \\
\hline 9 & $\mathrm{ABH}$ & 11 & 30 & 1.50 & 2008 & 2019 & 0.713 & 0.067 & 2 & 0.0924 \\
\hline 10 & $\mathrm{~A}(\mathrm{P}) \mathrm{TA}$ & 53 & 763 & 3.51 & 1985 & 2020 & 1.208 & 0.571 & 15 & 0.0920 \\
\hline 11 & $\mathrm{ABB}$ & 16 & 34 & 1.44 & 2005 & 2019 & 0.702 & 0.059 & 4 & 0.0691 \\
\hline 12 & АДВ & 18 & 192 & 3.50 & 2012 & 2017 & 0.326 & 0.786 & 6 & 0.0598 \\
\hline 13 & AAA & 57 & 95 & 1.80 & 2007 & 2019 & 0.241 & 0.211 & 4 & 0.0595 \\
\hline 14 & ATA & 22 & 71 & 2.68 & 2010 & 1029 & 0.245 & 0.338 & 3 & 0.0429 \\
\hline 15 & AAM & 7 & 31 & 2.86 & 2012 & 2017 & 0.261 & 0.032 & 3 & 0.0428 \\
\hline 16 & $\mathrm{~A}(\mathrm{O}) \mathrm{EE}$ & 18 & 122 & 4.20 & 2004 & 2018 & 0.385 & 0.057 & 5 & 0.0412 \\
\hline 17 & $\mathrm{~A}(\mathrm{E}) \mathrm{AB}$ & 71 & 72 & 2.27 & 2005 & 2020 & 0.463 & 0.458 & 4 & 0.0354 \\
\hline 18 & А(Б)ИВ & 161 & 634 & 10.08 & 1997 & 2019 & 0.952 & 0.696 & 10 & 0.0344 \\
\hline 19 & АИБ & 102 & 208 & 1.67 & 1992 & 2020 & 0.228 & 0.091 & 9 & 0.0330 \\
\hline
\end{tabular}




\begin{tabular}{|c|c|c|c|c|c|c|c|c|c|c|}
\hline \multicolumn{2}{|c|}{ ИсслеАователь } & \multicolumn{9}{|c|}{ Показатель } \\
\hline № & KoA & $\boldsymbol{P}_{\Sigma}$ & $C_{\Sigma}$ & $A$ & $Y_{1}$ & $Y_{\text {end }}$ & IF & $\alpha_{s c}$ & $\mathrm{H}$ & iiGI \\
\hline 20 & АЛВ & 10 & 4 & 1.00 & 2014 & 2019 & 0.239 & 0.000 & 2 & 0.0266 \\
\hline 21 & АВИ & 17 & 153 & 4.14 & 1997 & 2019 & 0.407 & 0.118 & 6 & 0.0251 \\
\hline 22 & АИЮ & 15 & 19 & 1.00 & 2004 & 2020 & 0.322 & 0.053 & 2 & 0.0226 \\
\hline 23 & ААИ & 38 & 160 & 2.98 & 2002 & 2020 & 0.211 & 0.406 & 5 & 0.0208 \\
\hline 24 & $\mathrm{~A}(\mathrm{P}) И И$ & 34 & 133 & 4.26 & 1997 & 2019 & 0.385 & 0.098 & 5 & 0.0205 \\
\hline 25 & AOB & 19 & 95 & 4.00 & 2004 & 2019 & 0.333 & 0.368 & 2 & 0.0195 \\
\hline 26 & $\mathrm{~A}(\mathrm{C}) \mathrm{AC}$ & 26 & 33 & 1.42 & 2002 & 2020 & 0.261 & 0.061 & 2 & 0.0175 \\
\hline 27 & ААЛ & 29 & 84 & 2.68 & 2005 & 2019 & 0.204 & 0.405 & 3 & 0.0169 \\
\hline 28 & AEB & 15 & 16 & 3.07 & 2010 & 2019 & 0.393 & 0.250 & 1 & 0.0154 \\
\hline 29 & АЮE & 30 & 37 & 1.23 & 2005 & 2018 & 0.131 & 0.135 & 3 & 0.0152 \\
\hline 30 & ААИ & 138 & 520 & 12.10 & 1996 & 2017 & 0.941 & 0.788 & 9 & 0.0149 \\
\hline 31 & AEA & 43 & 84 & 2.77 & 1996 & 2019 & 0.620 & 0.607 & 3 & 0.0128 \\
\hline 32 & АЮC & 146 & 940 & 2.43 & 1973 & 2019 & 0.203 & 0.643 & 8 & 0.0127 \\
\hline 33 & ААИ & 5 & 4 & 2.00 & 2014 & 2018 & 0.218 & 0.000 & 1 & 0.0121 \\
\hline 34 & A(Л)MB & 21 & 85 & 2.46 & 2006 & 2019 & 0.099 & 0.353 & 4 & 0.0113 \\
\hline 35 & $\mathrm{AB \Gamma}$ & 22 & 50 & 3.12 & 2008 & 2018 & 0.277 & 0.660 & 3 & 0.0105 \\
\hline 36 & АОД & 9 & 7 & 2.33 & 2016 & 2019 & 0.191 & 0.714 & 1 & 0.0102 \\
\hline 37 & AMA & 29 & 29 & 3.24 & 2010 & 2019 & 0.275 & 0.588 & 3 & 0.0101 \\
\hline 38 & AEB & 21 & 45 & 1.18 & 1998 & 2020 & 0.308 & 0.600 & 4 & 0.0097 \\
\hline 39 & АНИ & 13 & 45 & 3.86 & 1999 & 2018 & 0.497 & 0.267 & 4 & 0.0096 \\
\hline 40 & AOB & 7 & 18 & 1.57 & 2004 & 2019 & 0.235 & 0.111 & 2 & 0.0093 \\
\hline 41 & АДА & 23 & 6 & 4.41 & 2014 & 2019 & 0.616 & 0.667 & 1 & 0.0078 \\
\hline 42 & АГВ & 57 & 448 & 5.53 & 1963 & 2019 & 0.644 & 0.542 & 8 & 0.0074 \\
\hline 43 & $\mathrm{AHH}$ & 23 & 15 & 1.56 & 2006 & 2019 & 0.171 & 0.333 & 2 & 0.0056 \\
\hline 44 & АЮB & 56 & 56 & 1.69 & 1993 & 2019 & 0.133 & 0.321 & 4 & 0.0041 \\
\hline 45 & AAA & 7 & 9 & 3.88 & 2010 & 2020 & 0.257 & 0.556 & 2 & 0.0027 \\
\hline 46 & А(Л)ЛЮ & 38 & 66 & 2.15 & 1997 & 2021 & 0.394 & 0.894 & 3 & 0.0024 \\
\hline 47 & ATA & 25 & 39 & 9.00 & 1991 & 2019 & 0.492 & 0.103 & 3 & 0.0023 \\
\hline 48 & А(А)ИВ & 15 & 4 & 4.19 & 2011 & 2018 & 0.123 & 0.500 & 1 & $7.3 \cdot 10^{-4}$ \\
\hline 49 & $\mathrm{~A}(\mathrm{C}) И \mathrm{~B}$ & 120 & 202 & 8.22 & 2001 & 2020 & 0.461 & 0.980 & 6 & $6.3 \cdot 10^{-4}$ \\
\hline 50 & $\mathrm{~A}(\Pi) \mathrm{HH}$ & 14 & 8 & 3.07 & 1996 & 2020 & 0.145 & 0.875 & 1 & $8.2 \cdot 10^{-5}$ \\
\hline 51 & $\mathrm{AKH}$ & 15 & 5 & 3.62 & 2015 & 2018 & 0 & 0.600 & 1 & 0 \\
\hline 52 & AHO & 5 & 0 & 1.00 & 2008 & 2018 & 0 & 0.000 & 0 & 0 \\
\hline 53 & АВД & 16 & 0 & 1.63 & 2009 & 2019 & 0 & 0.000 & 0 & 0 \\
\hline
\end{tabular}

Примечание. Исходные данные взяты с официального сайта Научной электронной библиотеки eLIBRARY https://elibrary.ru (дата обращения: 06.06.2020):

$A$ - среднее количество авторов в публикации (рассчитыва-лось из распределения статей по количеству авторов - как среднее с весами, равными количеству статей для соот-ветствующего числа авторов);

$C_{\Sigma}-$ суммарное количество цитирований;

H - индекс Хирша;

IF - средневзвешенный импакт-фактор журналов, в которых были процитированы статьи;

$P_{\Sigma}-$ суммарное количество публикаций;

$Y_{1}$ - год опубликования первой работы;

$Y_{\text {end }}$ - год опубликования последней (индексированной в РИНЦ до 06.06.2020) работы;

$\alpha_{\mathrm{sc}}$ - доля цитирований соавторами.

С использованием $A, C_{\Sigma}$, IF, $Y_{1}$ и $\alpha_{\text {sc }}$ рассчитывался iiGl - улучшенный независимый Gl-index. 
В табл. П1 сортировка произведена по уменьшению iiGl, который, как видим, изменяется от 0 (у №№ 52, 53 - из-за того, что на их работы никто никогда не ссылался, и у № 51, поскольку на его статьи ссылки хотя и есть, но не из журналов с ненулевым импакт-фактором) до 0.67 у № 1. Впрочем, нулевое значение - это, конечно, совсем уж «клинический случай» (если, разумеется, речь не идет о первых статьях вчерашнего студента, на которые просто еще никто не успел сослаться). Но вот сравним, например, исследователей №№ 9 и 35 (их iiGl, соответственно, составляют 0.0924 и 0.0105). Оба опубликовали свои первые статьи в 2008 г., причем всего статей № 35 опубликовал даже в 2 раза больше, чем № 9, но статьи эти таковы, что на них ссылаются по большей части сами авторы (66\% ссылок) в весьма посредственных журналах (IF $=0.277)$, тогда как у № 9 ссылки соавторов составляют лишь $6.7 \%$, а $93.3 \%$ - независимые ссылки, причем ссылаются на него в журналах с IF $=0.713$. И государство, согласно предложению ДК, обоих должно «снабжать» одинаково? Почему? Разве это разумно? Не разумнее ли дать № 9 несколько больше средств, поскольку он уже доказал, что работать, в общем-то, худо-бедно, умеет?

\section{ПРИЛОЖЕНИЕ 2: О возМожНЫХ гендерных различиях публикационной результативности}

$\mathrm{K}$ сожалению, я не проводил систематического изучения данного вопроса и хочу обратить внимание читателей лишь на некоторые косвенные оценки. Вот, например, табл. П1 построена на основе данных для исследователеймужчин, носящих фамилию А-кий и женщин, имеющих аналогичную фамилию женского рода - А-кая. Оказывается, что мужчины составляют $32 \%$ от всех А-ких, а женщины $-68 \%$.
Аналогично можно проанализировать исследователей с любой другой фамилией. В табл. П2 приведено еще несколько примеров. Из табл. видно, что, хотя исследовательниц-женщин обычно больше, чем ученых мужей с аналогичной фамилией, но ссылок женщины набирают меньше (подчас - существенно меньше). Безусловно, на основании этих нескольких примеров нельзя делать сколько-нибудь общие выводы - анализ должен быть гораздо более широким и глубоким. Понятно, что может найтись несколько фамилий с обратной картиной (так должно быть в тех случаях, когда данная фамилия принадлежит, среди прочих, какой-либо выдающейся женщине-академику, но нет мужчин-академиков с аналогичной фамилией - пример: Белецкая; или когда данную фамилию носят только ученые женщины, но вообще в базе данных нет мужчин с аналогичной фамилией - примеры: Дедыш, Ножевникова). Кроме того, в табл. П2 использованы, в основном, данные по публикациям, индексированным в РИНЦ, а ДК в самом начале оговорил, что обсуждать будет только данные, полученные на основе WoS. Однако, согласитесь, тут есть над чем задуматься. Кстати, если говорить о данных $\mathrm{WoS}$, то хочу обратить внимание читателей на последние строки табл. П2 - для профессоров факультета почвоведения МГУ приведены именно данные $\mathrm{WoS}$, a не РИНЦ. Картина не изменилась. Более того, поскольку ДК затронул и такой параметр, как участие страны в самых цитируемых мировых публикациях, то важна будет и информация по количеству публикаций в Тор $25 \%$, поскольку именно для статей этих журналов велика вероятность стать наиболее цитируемыми. Итак, всего наши профессора (на 02.05.2020) опубликовали 72 статьи в журналах Тор25\%. Но профессора-женщины смогли опубликовать только 17 из них (т.е. лишь 24\%). 
Таблица П2. К попытке генАерного анализа результативности научной Аеятельности в РФ.

\begin{tabular}{|c|c|c|c|}
\hline \multirow{2}{*}{\multicolumn{2}{|c|}{ Группа ученых }} & \multicolumn{2}{|c|}{ Количество } \\
\hline & & \multirow{2}{*}{$\begin{array}{l}\text { публикаций } \\
735(37 \%) \\
\end{array}$} & \multirow{2}{*}{$\begin{array}{l}\text { цитирований } \\
5253(57 \%) \\
\end{array}$} \\
\hline А-кие & муж. (17 чел., т.е. 32\%) & & \\
\hline (53 чел.) & жен. (36 чел., т.е. 68\%) & $1241(63 \%)$ & $3929(43 \%)$ \\
\hline \multirow{2}{*}{$\begin{array}{l}\text { Глаголевы } \\
\text { (65 чел.) }\end{array}$} & муж. (30 чел., т.е. 46\%) & $2034(67 \%)$ & $27147(90 \%)$ \\
\hline & жен. (35 чел., т.е. 54\%) & $1001(33 \%)$ & $3082(10 \%)$ \\
\hline \multirow{2}{*}{$\begin{array}{l}\text { Карелины } \\
\text { (146 чел.) }\end{array}$} & муж. (73 чел., т.е. 50\%) & $2260(62 \%)$ & $12267(78 \%)$ \\
\hline & жен. (73 чел., т.е. 50\%) & $1374(38 \%)$ & $4498(27 \%)$ \\
\hline \multirow{2}{*}{$\begin{array}{l}\text { Пустовойтовы } \\
\text { (22 чел.) }\end{array}$} & муж. (12 чел., т.е. 55\%) & $374(83 \%)$ & $2058(83 \%)$ \\
\hline & жен. (10 чел., т.е. 45\%) & $74(17 \%)$ & $432(17 \%)$ \\
\hline \multirow{2}{*}{$\begin{array}{l}\text { Сабрековы } \\
\text { (6 чел.) }\end{array}$} & муж. (2 чел., т.е. 33\%) & $70(74 \%)$ & $327(94 \%)$ \\
\hline & жен. (4 чел., т.е. 67\%) & $24(26 \%)$ & $22(6 \%)$ \\
\hline \multirow{2}{*}{$\begin{array}{l}\text { Сирины } \\
\text { (13 чел.) }\end{array}$} & муж. (5 чел., т.е. $38 \%$ ) & $167(32 \%)$ & $2158(57 \%)$ \\
\hline & жен. (8 чел., т.е. 62\%) & $355(68 \%)$ & $1652(43 \%)$ \\
\hline \multirow{2}{*}{$\begin{array}{l}\text { Чепурных } \\
\text { (18 чел.) }\end{array}$} & муж. (6 чел., т.е. 33\%) & $103(37 \%)$ & $2730(58 \%)$ \\
\hline & жен. (12 чел., т.е. 67\%) & $172(63 \%)$ & $1977(42 \%)$ \\
\hline \multirow{2}{*}{$\begin{array}{l}\text { Профессора ф-та } \\
\text { Почвоведения МГУ* }\end{array}$} & муж. (11 чел., т.е. $48 \%$ ) & $372(48 \%)$ & $3107(62 \%)$ \\
\hline & жен. (12 чел., т.е. 52\%) & $404(52 \%)$ & $1927(38 \%)$ \\
\hline
\end{tabular}

*Примечание: Если сотрудник кроме должности профессора занимает какую-либо более высокую должность, например, заместителя декана, то в расчет он не включался. Данные взяты с официального сайта принятой в МГУ системы ИСТИНА [Садовничий, 2014]:

http://istina.msu.ru/ (даты обращения: 02.05 и 09.06.2020). Здесь же отметим, что в расчете возможны мелкие неточности (например, если сотрудник только что перешел на должность профессора, но информацию об этом в ИСТИНу еще внес).

\section{ПИTEPATYPA}

1. Васьковский В.Е. 1994. К вопросу о научных удоях // Химия и жизнь. №. 5. С. 84-85. [Vas'kovskiy V.E. 1994. K voprosu o nauchnykh udoyakh // Khimiya i zhizn'. V. 5. P. 84-85. (In Russian)].

2. Воробьев Г.Г. 1993. Легко ли учиться в американской школе? Книга для учителя. М.: Просвещение. 190 с. [Vorob'ev G.G. 1993. Legko li uchit'sya v amerikanskoy shkole? Kniga dlya uchitelya. M.: Prosveshchenie. 190 p. (In Russian)].

3. Вяйзя А.А., Киселев М.В., Дюкарев Е.А. 2019. Особенности температурного режима торфяных почв // Тринадцатое Сибирское совещание и школа молодых ученых по климато-экологическому мониторингу. Тезисы докладов российской конференции / Под ред. М.В. Кабанова. С. 170-171. [Vyayzya A.A., Kiselev M.V., Dyukarev E.A. 2019. Osobennosti temperaturnogo rezhima torfyanykh pochv // Trinadtsatoe Sibirskoe soveshchanie i shkola molodykh uchenykh po klimato-ekologicheskomu monitoringu. Tezisy dokladov rossiyskoy konferentsii / Pod red. M.V. Kabanova. P. 170-171 (In Russian)].

4. Галимов Э.М. 2012. Кому нужны лунные камни? М.: КРАСАНД. 576 с. [Galimov E.M. 2012. Komu nuzhny lunnye kamni? M.: KRASAND. 576 P.(In Russian)].

5. Глаголев М.В., Карелин Д.В., Франовский С.Ю. 2012. Могут ли индексы цитирования помочь в оценке уровня диссертаций? (Опыт сравнительного анализа в экологии) // Динамика окружающей среды и глобальные изменения климата. T. 3. № 1. C. 1-12. [Glagolev M.V., Karelin D.V., Franovskiy S.Yu. 2012. Could the citation indexes be helpful in quality analysis of dissertations: a case of comparative study in ecology // Environmental dynamics and global climate change. V. 3. No. 1. P. 1-12. (In Russian)].
6. Глаголев М.В., Лапшина Е.Д. 2012. Методика расчета эффективности научной деятельности в научно-образовательном центре ДОСиГИК ЮГУ // Динамика окружающей среды и глобальные изменения климата. Т. 3. № 2. C. 1-16. [Glagolev M.V., Lapshina E.D. 2012. The methodology for estimation of scientific activity efficiency in UNESCO department of Yugra State University // Environmental dynamics and global climate change. V. 3. No. 2. P. 1-16. (In Russian)].

7. Глаголев М.В., Сабреков А.Ф. 2008. 0 восстановлении плотности вероятности методом гистограмм в почвоведении и экологии // Динамика окружающей среды и глобальные изменения климата. № S1. C. 55-83. [Glagolev M.V., Sabrekov A.F. 2008. Reconstruction of probability density distribution by histogram method in soil science and ecology // Environmental Dynamics and Global Climate Change. No. S1. P. 55-83. (In Russian)].

8. Глаголев М.В., Сабреков А.Ф. 2014. Ответ А.В. Смагину: ІІ. Углеродный баланс России // Динамика окружающей среды и глобальные изменения климата. Т. 5. № 2. С. 50-70. [Glagolev M.V., Sabrekov A.F. 2014. A Reply to A.V. Smagin: II. Carbon Balance of Russia // Environmental Dynamics and Global Climate Change. V. 5. No. 2. P. 50-70. (In Russian)].

9. Глаголев М.В., Сабреков А.Ф., Терентьева И.Е. 2017. Ответ A.В. Смагину: IV. Поверхностная диффузия или случайный шум? // Динамика окружающей среды и глобальные изменения климата. T. 8. № 1. С. 55-65. [Glagolev M.V., Sabrekov A.F., Terentieva I.E. 2017. Reply to A.V. Smagin: IV. Surface diffusion or random noise? // Environmental dynamics and global climate change. V. 8. No. 1. P. 55-65. (In Russian)].

10. Глаголев М.В., Сабреков А.Ф., Филиппова Н.В., Лапшина Е.Д. 2018. Десять лет в победном строю: анализ деятель- 
ности журнала за первое десятилетие существования // Динамика окружающей среды и глобальные изменения климата. T. 9. № 2. С. 3-16. [Glagolev M.V., Sabrekov A.F., Filippova N.V., Lapshina E.D. 2018. Ten years of progress: Analytic review of the first decade of journal functioning // Environmental dynamics and global climate change. V. 9. No. 2. P. 3-16. (In Russian)]

11. Глаголев М.В., Суворов Г.Г. 2009. Элементы наукометрии в почвоведении и экологии (на примере факультета почвоведения МГУ) // Доклады по экологическому почвоведению. T. 10. № 1. 1-74. [Glagolev M.V., Suvorov G.G. 2009. Elements of scientometrics in soil science and ecology (by example of Faculty of soil science, Moscow state university) // Interactive Journal of Ecological Soil Science. V. 10. No. 1. P. 1-74. (In Russian)].

12. Киселев М.В., Дюкарев Е.А., Воропай Н.Н. 2019. Сезонномерзлый слой болот южно-таежной зоны Западной Сибири // Криосфера Земли. Т. 23. № 4. С. 3-15. [Kiselev M.V., Dyukarev E.A., Voropay N.N. 2019. Seasonally frozen layer of peatlands in the southern taiga zone of western Siberia // Earth's Cryosphere. V. 23. No. 4. P. 3-15. (In Russian)].

13. Кислицын С.А. 2013. Научная элита в системе политической власти. М.: Изд-во ЛКИ. С. 280. [Kislitsyn S.A. 2013. Nauchnaya elita v sisteme politicheskoy vlasti. Moscow: Izd-vo LKI. P. 280. (In Russian)].

14. Костылев А.А., Миляев П.В., Дорский Ю.Д., Левченко В.К., Чикулаева Г.А. 1991. Статистическая обработка результатов экспериментов на микро-ЭВМ и программируемых калькуляторах. Л.: Энергоатомиздат. 304 с. [Kostylev A.A., Milyaev P.V., Dorskii Yu.D., Levchenko V.K., Chikulaeva G.A. 1991. Statisticheskaya obrabotka rezul'tatov eksperimentov na mikroEVM i programmiruemykh kal'kulyatorakh. L.: Energoatomizdat. 304 P.(In Russian)].

15. Косых Н.П., Коронатова Н.Г., Лапшина Е.Д., Филиппова Н.В., Вишнякова Е.К., Степанова В.А. 2017. Линейный прирост и продукция сфагновых мхов в средней тайге Западной Сибири // Динамика окружающей среды и глобальные изменения климата. Т. 8. № 1. С. 3-13. [Kosykh N.P., Koronatova N.G., Lapshina E.D., Filippova N.V., Vishnyakova E.K., Stepanova V.A. 2017. Linear growth and production of Sphagnum mosses in the middle taiga zone of West Siberia // Environmental dynamics and global climate change. V. 8. No. 1. P. 3-13. (In Russian)].

16. Кривенок Л.А., Глаголев М.В., Фастовец И.А., Смоленцев Б.А., Максютов Ш.Ш. 2014. Удельные потоки метана из экосистем южной тундры Западной Сибири // Динамика окружающей среды и глобальные изменения климата. Т. 5. № 1. C. 26-42. [Krivenok L.A., Glagolev M.V., Fastovets I.A., Smolentsev B.A., Maksyutov S.S. 2014. Methane fluxes from south tundra ecosystems of West Siberia // Environmental Dynamics and Global Climate Change. V. 5. No. 1. P. 26-42. (In Russian)].

17. Кузьмин С.В. 2020. 0 корректировке государственного задания с учетом методики расчета комплексного балла публикационной результативности. М.: Министерство науки и высшего образования. [Kuz'min S.V. 2020.
0 korrektirovke gosudarstvennogo zadaniya s uchetom metodiki rascheta kompleksnogo balla publikatsionnoi rezul'tativnosti. M.: Ministerstvo nauki i vysshego obrazovaniya. (In Russian)].

18. Сабреков А.Ф., Глаголев М.В. 2016. 0 диссертации Н.А. Шнырева: І. Микрометеорология и другие замечания // Динамика окружающей среды и глобальные изменения климата. T. 7. № 2. C. 26-37. [Sabrekov A.F., Glagolev M.V. 2016. Thesis of N.A. Shnyrev: I. Micrometeorology and other notes // Environmental dynamics and global climate change. V. 7. No. 2. P. 26-37. (In Russian)]

19. Садовничий В.А. (ред.) 2014. Интеллектуальная система тематического исследования научно-технической информации (ИСТИНА). М.: Изд-во МГУ. 262 с. [Sadovnichii V.A. (red.) 2014. Intellektual'naya sistema tematicheskogo issledovaniya nauchno-tekhnicheskoi informatsii (ISTINA). Moskva: Izd-vo MGU. 262 p. (In Russian)].

20. Сойфер В.Н. 2002. Власть и наука. (Разгром коммунистами генетики в СССР). М.: ЧеРо. 1024 с. [Soyfer V.N. 2002. Communist Regime and Science. (Crushing of Genetics in the USSR by Communists). Moscow: CheRo. 1024 p. (In Russian)].

21. Шебаршин Л.В., Шебаршин А.Л. 2014. КГБ шутит. Афоризмы от начальника советской разведки и его сына. М.: Алгоритм. C. 25. [Shebarshin L.V., Shebarshin A.L. 2014. KGB shutit. Aforizmy ot nachal'nika sovetskoy razvedki i ego syna. Moscow: Algoritm. 25 P. (In Russian)].

22. Bowman A.W., Azzalini A. 1997. Applied Smoothing Techniques for Data Analysis. Oxford University Press.

23. Dyukarev E.A., Vyaizya A.A., Kiselev M.V. 2019. Differences in temperature regime of peat and mineral soil at Bakchar district of Tomsk region // Environmental dynamics and global climate change. V. 10. No. 2. P. 100-109. https://doi.org/10.17816/ edgcc21323

24. Glagolev M.V., Sabrekov A.F. 2019. Reply to A.V. Smagin: $\checkmark$. What is wrong with an "abiotic paper" and do we always need to take into account the abiotic gas absorption by soil? // Environmental Dynamics and Global Climate Change. V. 10. No. 1. P. 48-63. DOI: 10.17816/edgcc16144

25. Kapitonova O.A., Aksarina K.Yu. 2019. On some physical and chemical properties of soils of sandy outcrops of the West Siberian northern regions // Environmental dynamics and global climate change. V. 10. No. 1. P. 28-37.

26. Lawrence P.A. 2008. Lost in publication: how measurement harms science // Ethics in Science and Environmental Politics. V. 8. P. 9-11.

27. Terentieva I.E., Glagolev M.V., Sabrekov A.F., Lapshina E.D., Maksyutov S. 2016. Mapping of West Siberian taiga wetland complexes using Landsat imagery: implications for methane emissions // Biogeosciences. V. 13. No. 16. P. 4615-4626.

28. Vasilev A.A., Melnikov V.P., Semenov P.B., Oblogov G.E., Streletskaya I.D. 2019. Methane concentration and emission in dominant landscapes of typical tundra of western Yamal // Doklady Earth Sciences. V. 485. No. 1. P. 284-287.

29. Wuchty S., Jones B.F., Uzzi B. 2007. The Increasing Dominance of Teams in Production of Knowledge // Science. V. 316. Issue 5827. P. 1036-1039. DOI: 10.1126/science.1136099

Поступила в редакцию: 02.09.2020 Переработанный вариант : 13.11.202018

18 Несмотря на то, что статья была подана в раздел «Дискуссии» (для которого рецензирование по умолчанию не предполагается), авторы просили редакцию обеспечить ее рецензирование. В связи с этим данная статья проходила рецензирование в обычном порядке и после переработки была рекомендована к печати тремя независимыми рецензентами. - Примечание редактора. 